\title{
Geohistorical, didactic, and linguistic competencies learning through a bilingual (Spanish/English) fieldtrip project with teachers in training
}

\author{
Carlos Martínez-Hernández and Sara Albaladejo-Albaladejo* \\ doi: http://dx.doi.org/10.18543/tjhe-9(1)-2021pp65-102
}

Received: 3 March 2021

Accepted: 5 October 2021

\begin{abstract}
This research is predicated on the hypothesis that a fieldtrip project adhering to a CLIL (Content and Language Integrated Learning) philosophy can be effective in promoting learning of both social and linguistic competencies. The main objective was to evaluate the didactic efficacy of a bilingual urban itinerary with teachers in training (from bilingual and non-bilingual groups) to develop geohistorical, didactic and linguistic competencies. Procedural and consolidated learning was assessed, via a dossier of activities and a statistically validated pretestposttest. High development values were obtained in procedural tasks (average =

* Carlos Martínez-Hernández (corresponding author, cmartinezhernandez@ucm.es; https://orcid.org/0000-0002-6526-6905), Doctor in Geography, is PhD Assistant Lecturer in Didactics of Social Sciences in the Faculty of Education - Teacher Training Centre, at the Complutense University of Madrid (Spain).

Sara Albaladejo-Albaladejo (sara.albaladejo@um.es) is Associate Lecturer in the Faculty of Education at the University of Murcia (Spain).

More information about the authors is available at the end of this article.

Ethical statement and acknowledgements: The authors declare that they have no conflict of interest. The data collection for the research was carried out following the TJHE Ethical Guidelines for Publication and the Ethical Guidelines for International Comparative Social Research of the UNESCO code of ethics for research in Social Sciences, highlighting the anonymity, confidentiality, continuous information to the participants and the justification of the applied methods, which was endorsed by an external commission from ISEN Centro Universitario, the authors' work institution at the time of projecting the research. The research has been carried out within the framework of the KA2 Erasmus + Project of the European Union "STROLL, Walking the City - Streets Online" (Grant Number 2020-1-HU01-KA226HE-094111).
\end{abstract}


$8.8 / 10$ ), as well as a high increase in consolidated acquisition (average $=+24.5 \%$ students). The greatest growth was observed in language skills $(+26.4 \%)$. The assessed knowledge after the itinerary was significantly higher than before, for all competencies. However, there was no statistically significant difference between students belonging to bilingual or monolingual groups. Students positively valued these results. It is concluded that a local didactic fieldtrip is an effective CLIL strategy to develop social and linguistic competencies, and yet it is rarely discussed in the scientific literature and curricula.

Keywords: Didactic itinerary; bilingualism; competencies learning; geography; history; higher education; innovative project.

\section{Introduction}

Didactic fieldtrips to the nearby environment of the student conducted in a second language have not received much attention from either teaching practice or educational research. The focus is usually separate, either on the learning associated with the knowledge of the environment generated by the didactic fieldtrips, or on the linguistic learning that generates the use of a language in a transversal way.

These are two lines of action and research present in teacher training, where fieldtrips are conceived as a strategy to develop didactic and geohistorical competencies, and bilingualism, as a strategy to develop didactic and linguistic competencies.

However, within the framework of competency-based learning implemented in the EHEA, it is worth asking if it would be possible to carry out a didactic fieldtrip that, by both visiting the student's environment and using bilingualism, would allow the joint development of these geohistorical, didactic and linguistic competencies. This research explores a new path in the absence of similar studies.

\section{I.1. Learning by competencies}

Education is currently in a competency-based learning paradigm, which is present in European higher education through the EHEA (European Higher Education Area). ${ }^{1}$ Students become the protagonists of the teachinglearning process, in an active methodology, for the acquisition of professional

${ }^{1}$ Rosaria Lumino, and Paolo Landri, "Network time for the European Higher Education Area," Philosophy and Theory 109, no. 6 (2020): 522-543. 
competencies. ${ }^{2,3,4}$ In compulsory education, we speak of common "key competencies", ${ }^{5}$ but in higher education the competencies refer to professional skills depending on the field of training, considering labour, business, research and individual capabilities that lead to success. ${ }^{6}$ Acquiring competencies means achieving the knowledge, skills and attitudes necessary to adapt and respond to any situation, regardless of the context. ${ }^{7}$

According to López-Pastor, Molina, Pascual, and Manrique, the active methodology that best allows the achievement of the competencies that university education requires is dialogic learning. ${ }^{8,9}$ However, traditional learning still predominates in higher education. ${ }^{10}$ Faced with this, a didactic and methodological change from the different areas of knowledge is the starting point towards the development of competencies. The training of teachers and their change of attitude is essential. In this change, the organization of the didactic action will also become relevant for the construction of learning based on the acquisition of competencies. EHEA is still working on it. ${ }^{11}$

2 Ramón Vicente López Facal, “Competencies and social sciences teaching [Competencias y enseñanza de las ciencias sociales]," Íber: Didáctica de las ciencias sociales, geografía e historia 74 (2013): 5-8.

3 Víctor Manuel López-Pastor, "The rol of formative assessment in competency assessment: contributions from the formative and shared assessment in higher education network," Revista de Docencia Universitaria 9, no. 1 (2011): 159-73.

${ }^{4}$ Finn Mogensen, and Karsten Schnack, "The action competence approach and the 'new' discourses of education for sustainable development, competence and quality criteria," Environmental Education Research 16, no. 1 (2010): 59-74.

${ }^{5}$ Gábor Halász, and Alain Michel "Key Competences in Europe: interpretation, policy formulation and implementation," European Journal of Education, Research, Development and Policy 46, no. 3 (2011): 289-306.

${ }^{6}$ Outi Kallioinen, "Defining and Comparing Generic Competences in Higher Education," European Educational Research Journal 9, no. 1 (2010): 56-68.

7 José Tejada, "The alternation of contexts aimed to the acquisition of competencies in complementary settings of higher education: concepts and strategy," Educación XX1 15, no. 2 (2012): 17-40.

${ }^{8}$ Víctor Manuel López-Pastor, et al., "The importance of using Formative and Shared Assessment in Physical Education Teacher Education: Tutored Learning Projects as an example of good practice," Retos. Nuevas tendencias en Educación Física, Deporte y Recreación 37 (2020): 620-27.

${ }^{9}$ Paulo Freire, Political nature of Education: culture, power and liberation [La naturaleza política de la Educación: Cultura, Poder y Liberación] (Barcelona: Paidos-MEC, 1990).

${ }^{10}$ Juan Antonio Rodríguez, and Pablo Joel Santana, "The distance between teachers' and students' work in EHEA: A dangerous gap?", Profesorado. Revista de Currículum y Formación de Profesorado 19, no. 3 (2015): 380-404.

${ }^{11}$ Sjur Bergan, "The European Higher Education Area: A road to the future or at way's end?" Tuning Journal for Higher Education 6, no. 2 (2019): 23-49. 
Good practices in the educational field are determined by active learning and an innovative character, in which the result is effective and efficient and can be systematized and extrapolated. In addition, good practices must be essential, core and quantifiable, responding to all identified needs. ${ }^{12}$

\section{I.2. Didactic fieldtrips as good practices to acquire competencies}

An urban itinerary, as a type of didactic fieldtrip, can be an appropriate example of good practice due to the possibilities in dialogic learning and the development of competencies from an interdisciplinary approach. It is a group fieldwork activity in urban space intended to motivate students and promote their personal development. ${ }^{13}$

At the time of undertaking this evolution of university education and of the teaching mentality, educational proposals arise that are approached jointly between various subjects (i.e., in an interdisciplinary way). As Lavega, Sáez de Orcáriz, Lasierra, and Salas point out, these present a series of benefits ${ }^{14}$ such as the active involvement of both students and teachers or the integration of the knowledge and competencies shared by the different subjects involved. The different personal competencies that facilitate interdisciplinary proposals, such as collaboration, communication or informal learning, among others, are essential elements of 21 st century learning ${ }^{15}$ and coincide with competency benefits that many authors attribute to didactic fieldtrips. ${ }^{16}$

According to Crespo, Gómez, \& Cruz, fieldtrips facilitate a holistic understanding of the environment in which they operate, favouring the development of multicausal understanding of spatial processes, factors and elements, ${ }^{17}$ and therefore a competency learning. This circumstance

12 Javier Fombona, and María Ángeles Pascual, Adult education, approach based on the analysis of European good practices. Revista Complutense de Educación 30, no. 2 (2019): 647-65.

${ }_{13}$ Carlos Martínez-Hernández, and Claudia Yubero, "Explaining Urban Sustainability to Teachers in Training through a Geographical Analysis of Tourism Gentrification in Europe," Sustainability 12, no. 1 (2020): 67.

${ }^{14}$ Pere Lavega, et al., "Intradisciplinarity and Interdisciplinarity in the acquisition of competencies: a study of a cooperative learning experience," Revista Electrónica Interuniversitaria de Formación del Profesorado 16, no. 1 (2013): 133-45.

${ }^{15}$ Christine Redecker, and Yves Punie, "The future of learning 2025: developing a vision for change," Future Learning 1 (2013): 3-17.

${ }^{16}$ David Aguilera, "Field trip as a didactic resource to teach sciences. A systematic review," Revista Eureka sobre Enseñanza y Divulgación de las Ciencias 15, no. 3 (2018): 3103-19.

${ }_{17}$ José Manuel Crespo, María Luisa Gómez, and Luis Alfonso Cruz, "An approach to the National Parks landscapes and educational itineraries," Espacio, Tiempo y Forma 11 (2018): 121-140. 
turns fieldtrips into a strategy of proven efficacy in the didactics of different disciplines, such as Geography, History, Art, Natural Sciences, Physical Education... ${ }^{18,19,20}$ as well as for interdisciplinary learning, ${ }^{21}$ in urban $^{22}$ or natural environments. ${ }^{23}$ The Manifesto for Learning Outside the Classroom emphasizes that any young person should experience the world beyond the classroom, as an essential part of learning and personal development. ${ }^{24}$ In addition, didactic fieldtrips allow the development of observation, inquiry and discussion, elements involved in the motivation of students..$^{25}$

Despite the long historical journey of didactic experiences outside the classroom, Pedrinaci points out that the current number of didactic fieldtrips is relatively low, which produces a sensation of novelty in the student. ${ }^{26}$ Peasland, Henri, Morrell, \& Scott point out that higher education should include more training in field work. ${ }^{27}$ Domínguez Almansa \& López Facal demonstrate the didactic benefits of carrying out fieldtrips outside the classroom in the development of competencies of teachers in training..$^{28}$

18 Silvia Aparecida Sousa Fernandes, Diego García Monteagudo, and Xosé Manuel Souto González, "Educación geográfica y las salidas de campo como estrategia didáctica: un estudio comparativo desde el Geoforo Iberoamericano," Biblio3W, Revista Bibliográfica de Geografía y Ciencias Sociales 21, no. 1155 (2016): 1-22.

19 James Farmer, Doug Knapp, and Gregory M. Benton, “An Elementary School Environmental Education Field Trip: Long-Term Effects on Ecological and Environmental Knowledge and Attitude Development," The Journal of Environmental Education 38, no. 3 (2007): 33-42.

${ }^{20}$ Antonio Granero-Gallegos, and Antonio Baena-Extremera, Physical activities in natural areas: Theory and practice for Physical Education [Actividades físicas en el medio natural: Teoría y práctica para la Educación Física] (Sevilla: Wanceulen, 2010).

${ }^{21}$ Pilar Benejam, "The aims of fieldtrips," Iber: Didáctica de las ciencias sociales, geografía e historia 36 (2003): 7-12.

${ }_{22}$ Carlos Martínez-Hernández and Cladia Yubero, "Explaining urban”, 67.

${ }^{23}$ Ryan G. Dale, et al., "Influence of the natural setting on environmental education outcomes," Environmental Education Research 26, no. 5 (2020): 613-31.

${ }^{24}$ Council for Learning Outside the Classroom, Learning Outside the Classroom. Manifesto (Nottingham: DfES Publications, 2006).

${ }^{25}$ Cecily Jane Maller, "Promoting children's mental, emotional and social health through contact with nature: a model," Health Education 109, no. 6 (2009): 522-43.

${ }^{26}$ Emilio Pedrinaci, "Fieldwork and sciences learning [Trabajo de campo y aprendizaje de las ciencias]," Alambique: Didáctica de las Ciencias Experimentales 71 (2012): 81-9.

${ }^{27}$ Emma Peasland, et al., "The influence of fieldwork design on student perceptions of skills development during field courses," International Journal of Science Education 41, no. 17 (2019): 2369-88.

${ }^{28}$ Andrés Domínguez Almansa, and Ramón Vicente López Facal, "Heritage, landscape and education: initial teacher education and civic education of pupils in primary," CLIO. History and History teaching 40 (2014): 1-26. 
Since fieldtrips are very effective for the development of social sciences competencies (geographical, historical and didactic), in this research we propose an enrichment of their disciplinary effectiveness through the incorporation of linguistic competencies within the framework of bilingualism.

\section{I.3. Didactic fieldtrips in the teaching of languages}

Bilingual programs involve the use of two languages as teaching tools ${ }^{29}$ so that teaching is done using the foreign tongue but without teaching the language as the main content. There are numerous studies that demonstrate the advantages of this type of education, among others, in the cognitive and linguistic development of students..$^{30}$ On the other hand, there is also evidence that, in certain subjects, especially those related to science, learning is limited to memorizing vocabulary and does not deepen the understanding of or ability to interact with the environment ${ }^{31}$ That is why choosing an appropriate method and strategies is essential.

One of the most widespread bilingual methods is "Content and Language Integrated Learning" (CLIL). It is a dynamic approach that aims to create situations in which communication takes place naturally, ${ }^{32}$ promoting all kinds of communicative activities, so valued in multilingualism. ${ }^{33}$ In other words, the most important thing is not the correct use of the language, but the understanding of the content to be able to interact in the foreign language. ${ }^{34}$ With this aim as a starting point, it is possible to work on contents by creating authentic learning contexts, multidisciplinary projects, or tasks in which students have an active role and must act cooperatively. ${ }^{35}$ These characteristics

${ }^{29}$ Liz Dale, and Rosie Tanner, CLIL Activities: A resource for subject and language teachers (Cambridge: Cambridge University Press, 2012).

${ }^{30}$ Melody Wiseheart, Mythili Viswanathan, and Ellen Bialystok, "Flexibility in task switching by monolinguals and bilinguals," Bilingualism: Language and Cognition 19, no. 1 (2015): 141-6.

31 Jasone Cenoz, Fred Genesee, and Durk Gorter, "Critical analysis of CLIL: Taking stock and looking forward," Applied Linguistics 35, no. 3 (2014): 243-262.

${ }^{32}$ Christian Abello-Contesse, "Bilingual and multilingual education: An overview of the field," in Bilingual and multilingual education in the 21st century: Building on experience, ed. Christian Abello-Contesse et al. (Bristol: Multilingual Matters, 2013), 2-23.

33 Anne Biedermann, "Linguistic mediation in a foreign language teaching context," Synergies Chili 10 (2014): 83-91.

${ }^{34}$ Do Coyle, "Content and Language Integrated Learning: Towards a Connected Research Agenda for CLIL Pedagogies," The International Journal of Bilingual Education and Bilingualism, 10, no. 5 (2007): 543-62.

${ }_{35}$ Esther Cristóbal-Aragón, and Ileana M. Greca, "Science teaching in a bilingual context: proposal for teaching an Astronomy content," Revista de Enseñanza de la Física, 30, no. 2 (2018): 31-47. 
mean that this method has been considered effective, with adequate strategies, for teaching non-language subjects. ${ }^{36,37}$

Fieldtrips in language teaching are not usually part of CLIL programs and are more focused on linguistic and cultural immersion trips, usually abroad.$^{38}$ However, immersion experiences, in addition to requiring financial and logistical efforts, are based on a non-bilingual conception of language learning, with its own attendant characteristics, which also make them very effective. ${ }^{39}$ A recent trend in bilingual teaching is the virtualization of immersion, so as not to disconnect from the native environment, with applications such as "Street View" ${ }^{40}$ artificial intelligence ${ }^{41}$ or virtual

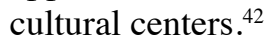

In any case, these are initiatives that seek to develop linguistic and cultural competencies, leaving aside other more curricular competencies. We wonder, then, if it is possible to design a fieldtrip that seeks the acquisition of competencies more typical of social sciences and also incorporates the development of linguistic competencies in a bilingual framework. If a didactic fieldtrip with teachers in training for geographical and historical purposes is carried out combining the mother tongue and a foreign language that is part of the curriculum, will its effectiveness be maintained in the development of geohistorical and didactic competencies and, even more, will it be possible to incorporate language competencies? Is it possible, in short, to conduct a fieldtrip in accordance with CLIL philosophy?

${ }^{36}$ Nashwa Nashaat-Sobhy and Ana Llinares, "CLIL students' definitions of historical terms," International Journal of Bilingual Education and Bilingualism, in press (2020).

37 Aintzane Doiz, David Lasagabaster, and Juan Manuel Sierra, "CLIL and motivation: The effect of individual and contextual variables," The Language Learning Journal 42, no. 2 (2014): 209-24.

${ }^{38}$ Montserrat Mir, "Teaching and learning about Spanish L2 compliments in short-term study abroad," Study Abroad Research in Second Language Acquisition and International Education 5, no. 2 (2020): 230-57.

39 Sean Grant, "Effects of intensive EFL immersion programmes on willingness to communicate," Language Learning Journal 48, no. 4 (2020): 442-53.

${ }^{40}$ Samuel Chabot, et al., "Language learning in a cognitive and immersive environment using contextualized panoramic imagery," in HCI International 2019 - Posters. HCII 2019. Communications in Computer and Information Science, 1034, ed. Constantine Stephanidis (Cham: Springer, 2019), 202-9.

${ }^{41}$ Benjamin Chang, et al., 2012. "Foreign language learning in immersive virtual environments" (paper presented at "Proceedings of SPIE - the International Society for Optical Engineering 8289”, Burlingame, California, 8 February 2012).

${ }^{42}$ N. Eleni Pappamihiel and Jennifer Hatch Knight, "Using digital storytelling as a language experience approach activity: Integrating English language learners into a museum field trip," Childhood Education 92, no. 4 (2016): 276-80. 


\section{I.4. Research approach and objectives}

Considering what has been previously stated about learning by competencies, the strategy of an urban itinerary as a possibility within active methodologies and the possibilities of bilingual education, the hypothesis is established that a didactic fieldtrip with CLIL philosophy can be didactically effective. In this way, research has been proposed on the didactic effectiveness of the application of a bilingual urban itinerary (Spanish, as the mother tongue, and English, as the first foreign language, EFL) in the acquisition of geohistorical, linguistic and didactic competencies by teachers in training. The research questions (RQ) that are intended to be answered, aimed at demonstrating the hypothesis raised, are:

RQ1. Is the design of an urban itinerary feasible to develop geohistorical, linguistic and didactic competencies?

RQ2. To what degree and in what way would the application of this itinerary be didactically effective?

RQ3. Would there be a significant change in knowledge in students after its completion?

RQ4. Would there be significant differences depending on whether the students belong to a bilingual training group?

RQ5. Would motivation and satisfaction awaken on the part of the students?

Based on these questions, the general objective (GO) of this work is defined as assessing the didactic effectiveness of an urban itinerary designed and carried out with teachers in training, depending on whether they belong to a bilingual training group already through five specific objectives (SO):

SO1. Present the design of the urban itinerary $(R Q 1)$.

$\mathrm{SO} 2$. Establish and validate an itinerary assessment system (RQ1).

SO3. Assess the level of procedural learning in the acquisition of geohistorical, linguistic and didactic competencies during the itinerary (RQ2 and RQ4).

SO4. Evaluate the level of comprehensive learning after the acquisition of geohistorical, linguistic and didactic competencies during the itinerary (RQ2, RQ3 and RQ4).

SO5. Assess the student's assessment of the usefulness and logistics of the itinerary (RQ5). 


\section{Materials and methods}

The research has been based on a quasi-experimental methodology ${ }^{43}$ with a quantitative approach, in which a cross-sectional strategy has been followed and in which the procedure for assigning participants to the research has been laid out. To obtain information, a series of data collection instruments have been used. Finally, different statistical analyses of the results have been carried out.

\section{II.1. Participants and study area}

A total of 27 students from a University Degree in Primary Education (ISEN, University of Murcia, Spain) participated in the itinerary, with an average age of $23.5 \pm 4.6$ years. $67 \%$ belong to a bilingual group (EFL) and the remaining $33 \%$ do not. $63 \%$ are women and $37 \%$ are men. From this characterization, the circumstance of belonging or not to a bilingual group has been used for the investigation, through the nominal variable "bilingual", with response categories of "yes" and "no".

The itinerary took place in the Spanish city of Cartagena (Spanish as the native language), where the study centre of the participants is located and which constitutes its urban reference area. There is consensus on the idea that carrying out a teaching activity in a well-known place contributes to achieving more meaningful and motivating learning. ${ }^{44}$ In addition, the city has wideranging urban characteristics ${ }^{45}$ that allow the design of an itinerary focused on geohistorical aspects.

\section{II.2. Activity design}

The activity was presented to the students in the form of a complementary workshop to their training, lasting a total of 12.5 hours over three days,

43 Thomas D. Cook, Donald T. Campbell, and Laura Peracchio "Quasi experimentation," in Handbook of industrial and organizational psychology, ed. Marvin D. Dunnette and Leaetta M. Hough (Sunnyvale: Consulting Psychologists Press, 1990), 491-576.

${ }^{44}$ Joan Pagès, "Teaching and learning social sciences in 21 st Century [Enseñar y aprender ciencias sociales en el siglo XXI: reflexiones casi al final de una década]," in Investigación en Educación, Pedagogía y Formación Docente: La investigación al servicio de una educación incluyente y de calidad en un mundo diverso y globalizado, ed. several authors (Antioquía: Universidad Pedagógica Nacional, Universidad de Antioquía, Corporación Interuniversitaria de Servicios, 2009), 139-154.

${ }^{45}$ Emilio José López Salmerón, “The creation of a city: urbanistic evolution of Cartagena [La creación de una ciudad: evolución urbanística de Cartagena]" (PhD Diss., University of Alicante, Spain, 2017). 
within the official educational offer of the University of Murcia's Own Studies service, under the title of "Workshop Teaching History and Geography in English: walking around Cartagena". The Workshop pursued a three didactic objective: (i) develop geographical skills, (ii) to make the historical learning revealed through urban heritage more meaningful, (iii) in a bilingual linguistic framework that allows the natural use of English in pedagogical tasks with a local focus. The students were provided with a Dossier of activities in Spanish and English with all the logistical and academic information. A structure in three phases ( $\mathrm{SOl}$ ) was established (one per day), based on an interaction in the foreign language of training (English) with specific support in the native language (Spanish):

1. Preparation: online materials for each stop in the itinerary for home consultation prior to performing the exercise to ensure all students were starting from the same knowledge and were suitably motivated.

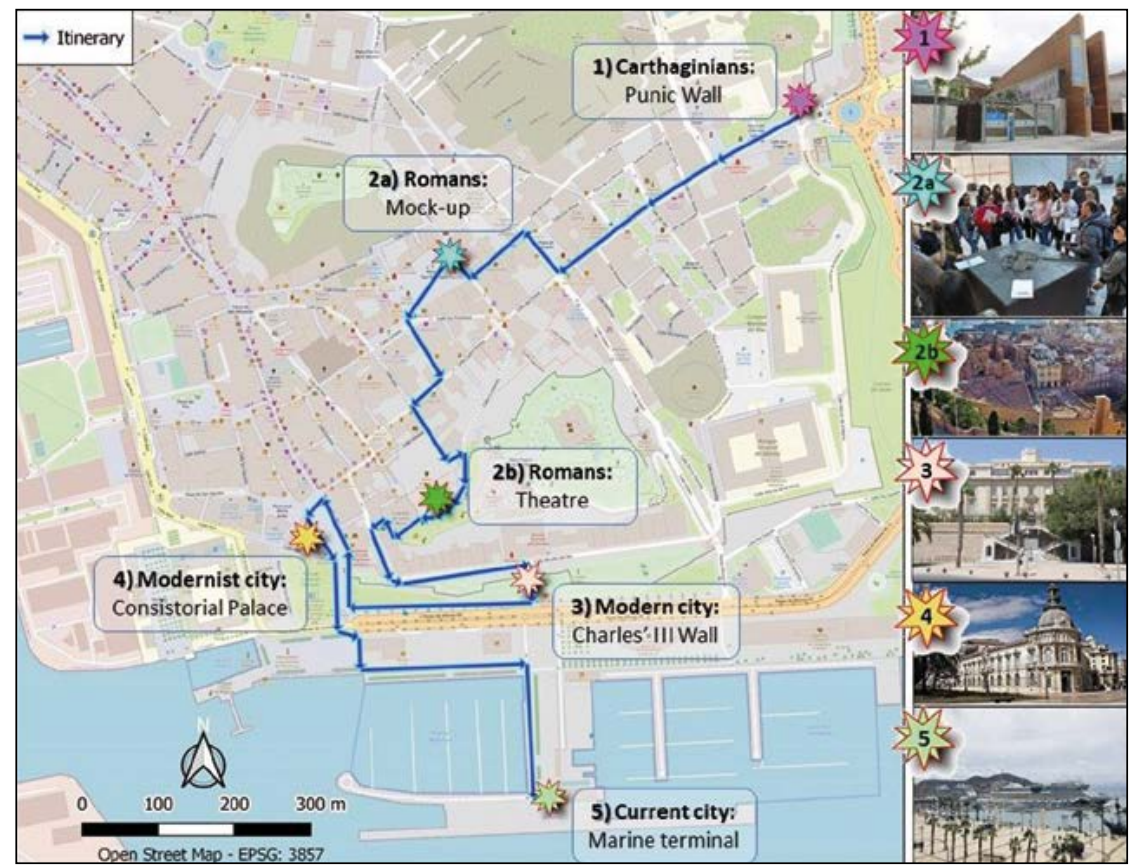

Figure 1

Itinerary with geographical locations and pictures of each stop (For further information see Table 1) 


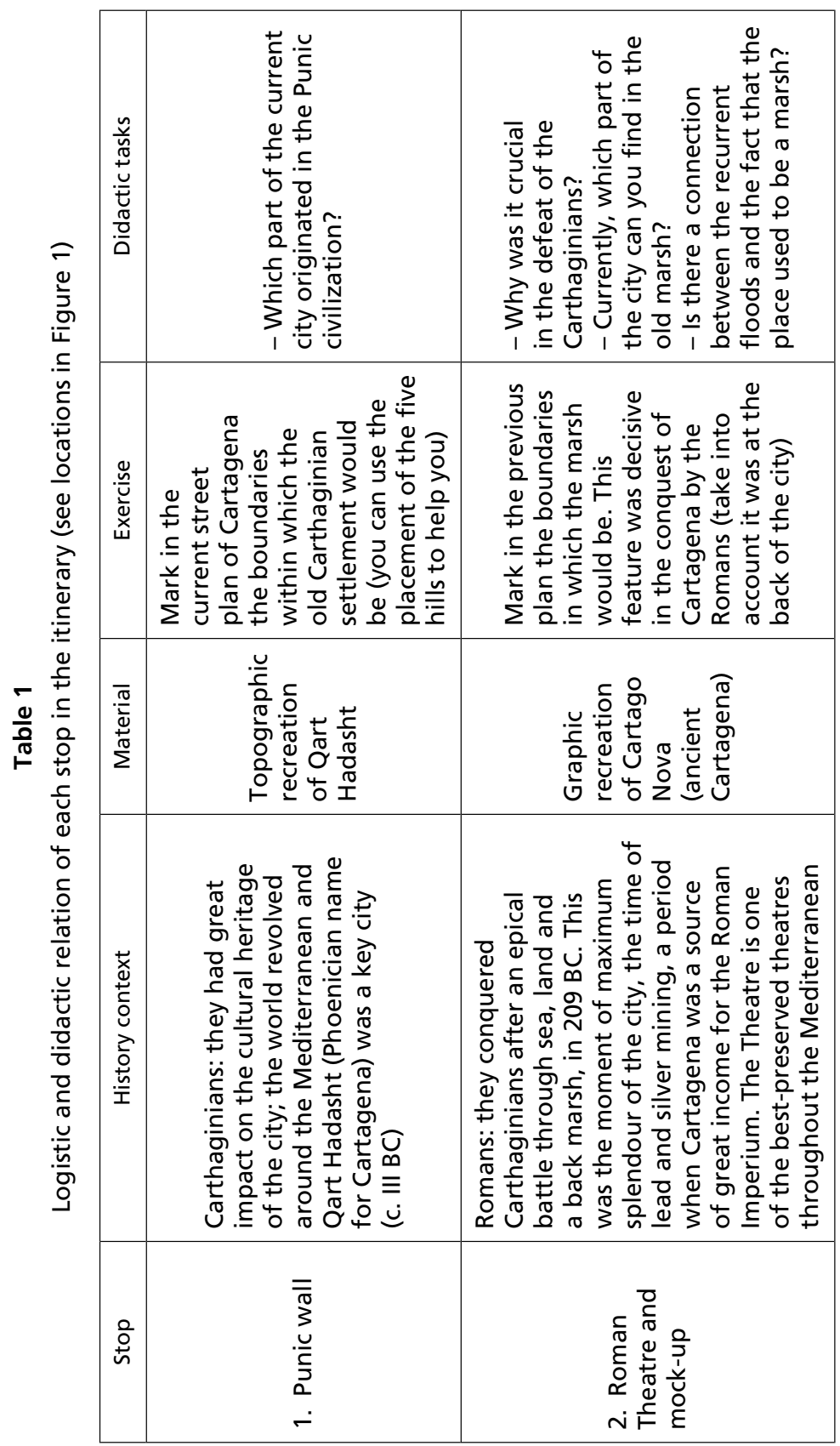

Tuning Journal for Higher Education 


\begin{tabular}{|c|c|c|c|}
\hline 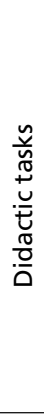 & 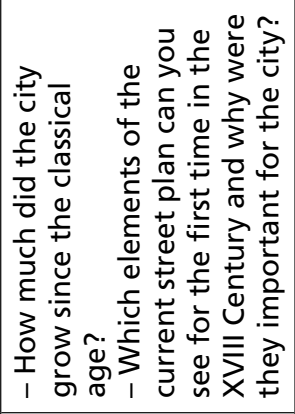 & 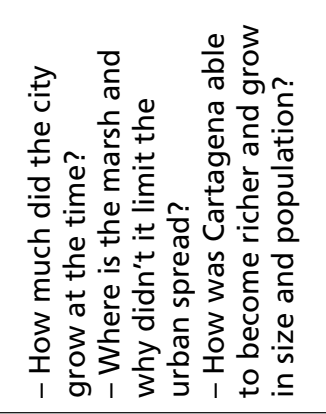 & 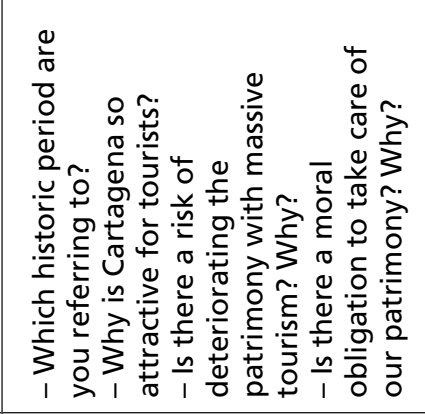 \\
\hline & 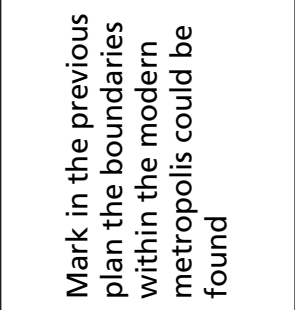 & 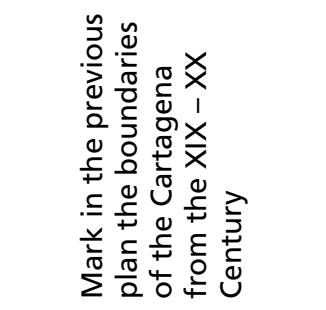 & 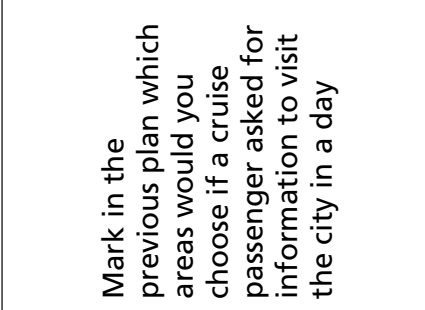 \\
\hline & 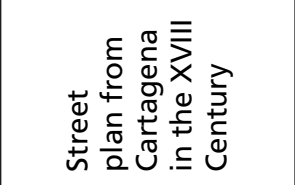 & 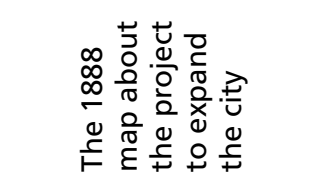 & 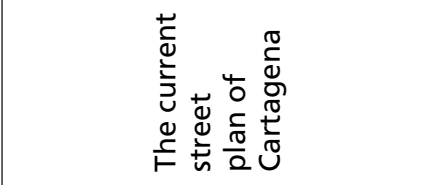 \\
\hline 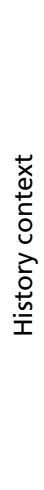 & 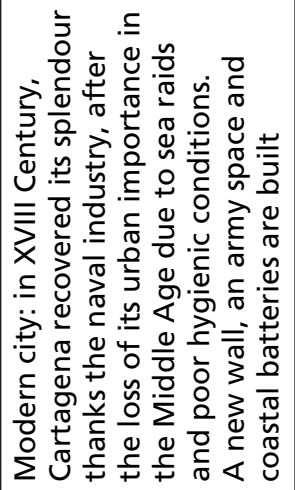 & 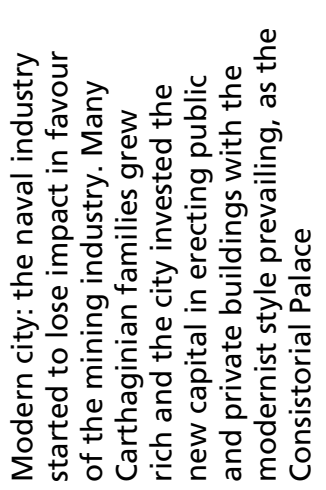 & 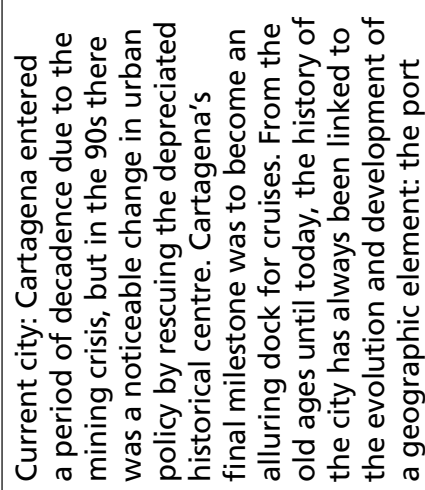 \\
\hline $\begin{array}{l}\text { 을 } \\
\text { ثे }\end{array}$ & 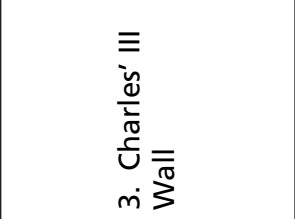 & 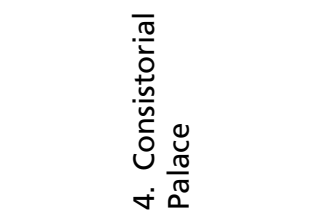 & 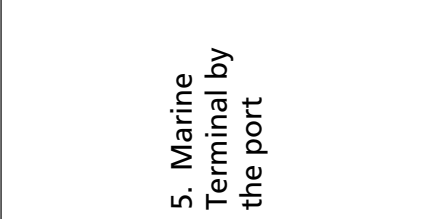 \\
\hline
\end{tabular}


2. Itinerary: connection route between five representative points of a relevant historical moment in the city, conceived as successive stops based on the historical chronology itself (Figure 1). During the tour, the students had to indicate the route followed on a street map of the city designed in English and, at each stop, after listening to the teachers' presentations (itinerary guides), solve from the Dossier of activities an exercise of geographical focus to promote historical thinking (Table 1), in English.

3. Teaching exploitation: within a week after the itinerary, sending a teaching proposal in English for primary education based on an urban itinerary, following a model with the main elements of a teaching plan (course, subject, objectives, competencies, contents, methodology, resources, activities, sequence and evaluation).

\section{II.3. Learning assessment}

In this research, learning has been defined as the acquisition of geographic competencies, historical thinking, English as a foreign language skills, and didactic projection capacity. Geographical learning refers to the capacity for location and orientation, awareness of historical dependence on natural elements and critical thinking to interpret reality. Historical learning follows a temporal axis that finds its physical foothold in urban heritage, so that the student is able to learn history, see it in their daily lives and develop a civic awareness towards the material and immaterial legacy. When we want to focus on the relationship between geographical and historical competencies, which are practically unavoidable in this activity, we speak of geohistorical competencies. Language learning is framed within the bilingual background of the entire activity, concretized in the combination of interventions in English and Spanish (FL and mother tongue), both in reception and expression tasks. Finally, didactic learning is materialized with the planning of a teaching proposal comprising the knowledge acquired during the workshop.

In order to quantify the acquisition of these competencies (SO2), three assessment procedures were carried out (Table 2). The first consisted of the comparative analysis of a pre-test and a post-test, by filling in a questionnaire by the students in two phases (before starting the activity and once it was finished) with questions structured in three thematic blocks: Geography (five multiple-choice questions), History (nine multiple-choice questions), and English (seven short-answer questions). In the second phase questionnaire, a student assessment block was added, with eight items to be scored with a Likert scale from 1 to 5 from lowest to highest level of agreement on logistical, 
motivational and didactic awareness issues, in addition to a question inviting free comment. The second assessment procedure consisted of the elaboration of a learning matrix with the difference between the values of the thematic blocks of the second phase of the questionnaire and the first. The third assessment was the completion of the Dossier of activities, made up of three groups of tasks: marking the itinerary on a map, carrying out practical exercises at the stops on the itinerary and designing the teaching proposal.

\section{Table 2}

Summary of the assessment tools

\begin{tabular}{|l|l|l|}
\hline \multicolumn{1}{|c|}{ Procedure } & \multicolumn{1}{|c|}{ Tool } & $\begin{array}{l}\text { Phase (see } \\
\text { section 2.2) }\end{array}$ \\
\hline \multirow{2}{*}{$\begin{array}{l}\text { Comparative } \\
\text { analysis }\end{array}$} & $\begin{array}{l}\text { Pre-test questionnaire with blocks of questions } \\
\text { about Geography, History and English }\end{array}$ & $\begin{array}{l}\text { Before } \\
\text { Phase I }\end{array}$ \\
\cline { 2 - 3 } & $\begin{array}{l}\text { Post-test questionnaire with blocks of questions } \\
\text { about Geography, History, English and satisfaction }\end{array}$ & $\begin{array}{l}\text { After } \\
\text { Phase III }\end{array}$ \\
\hline $\begin{array}{l}\text { Statistical } \\
\text { elaboration }\end{array}$ & $\begin{array}{l}\text { Learning matrix comparing the values of the } \\
\text { thematic blocks in the pre- and post-questionnaires }\end{array}$ & $\begin{array}{l}\text { After } \\
\text { Phase III }\end{array}$ \\
\hline $\begin{array}{l}\text { Analysis } \\
\text { of student } \\
\text { completion }\end{array}$ & $\begin{array}{l}\text { Dossier of activities: itinerary map, practical } \\
\text { activities for each stop, and design of the teaching } \\
\text { proposal }\end{array}$ & $\begin{array}{l}\text { During } \\
\text { Phase II } \\
\text { and III }\end{array}$ \\
\hline
\end{tabular}

\section{II.4. Statistical analysis}

The completion of the instruments that make up the assessment questionnaire was positively subjected to a degree of validity study (SO2) using the Cronbach's Alpha test. It has yielded a very high level of consistency of the set of responses in the case of the pre-test $(\alpha=0.92)$ and a high level in the post-test $(\alpha=0.62)$ and when considering only the student assessment block $(\alpha=0.65)$.

To obtain comprehensive learning results ( $\mathrm{SO} 4)$, a variable was configured per thematic block, based on the sum of correct answers in their questions, for the pre-test, post-test and the learning matrix. For multiplechoice cases (Geography and History), the scoring is objective; for the short answer (English), an interpretation was used according to two joint criteria: vocabulary management and response coherence. The resulting ordinal variables were: "Geography" (range 1:5), "History" (range 1:9) and "English" (range 1:7). The grouping variables "Geo + History" were also established for the set of responses to the questions of Geography and History and "Global" to consider all the responses to the questionnaire, both ordinal. For 
the post-test, the continuous variable "Satisfaction" (range 1:5) was added from the arithmetic mean of the items in the student assessment block (SO5).

The pretest, conceived as prior knowledge, was completed by the 27 participants; the post-test (later knowledge), by 13; the difference between prior and subsequent knowledge, conceived as consolidated comprehensive learning, has therefore been calculated for the 13 participants who have been assessed throughout the process.

The procedural tasks of the Dossier of activities (SO3), completed by 24 participants, were scored on a continuous scale from 0 to 10 from lowest to highest correction, obtaining four continuous variables: "mapping", for the task of marking the itinerary on a Street map; "Notebook", for the exercises performed at the stops; "Teaching proposal", for the design of the teaching proposal; and, finally, "Average", for the arithmetic mean of the set of tasks derived from the Dossier, conceived as procedural learning.

Of all these variables, compiled in Table 3, descriptive and inferential analyses were carried out using Excel (Microsoft) and SPSS v.25 (IBM) programs.

Table 3

Research variables

\begin{tabular}{|c|c|c|}
\hline Variable & Type & Tool \\
\hline Geography & \multirow{5}{*}{ Ordinal } & \multirow{5}{*}{ Pre-test + Post-test + Learning matrix } \\
\hline History & & \\
\hline English & & \\
\hline Geo + History & & \\
\hline Global & & \\
\hline Satisfaction & \multirow{5}{*}{ Continuous } & Post-test \\
\hline Mapping & & \multirow{4}{*}{ Dossier of activities } \\
\hline Notebook & & \\
\hline Teaching proposal & & \\
\hline Dossier's Average & & \\
\hline
\end{tabular}

In the descriptive analyses, frequencies (percentages of students with correct answers) and measures of central tendency (mean and median) and variability (quartiles and standard deviation) were calculated. In the inferential analyses, two sets of contrast tests were carried out for the null hypothesis of no 
significant differences with p-value $<.05$ : (i) between the variable "bilingual" and the rest of the research variables, to determine if there are significant differences in learning between belonging to a bilingual group or not; and (ii) between the variables that define knowledge prior to the itinerary and the variables of subsequent learning, to check whether the change in knowledge produced is statistically significant. In the case of ordinal variables, nonparametric tests were performed: ${ }^{46}$ Mann-Whitney U for independent samples (pre-test and post-test variables) and Wilcoxon signed range test for related samples (variables of the learning matrix). In the case of continuous variables, contrast tests were determined by the Shapiro-Wilk test of normality $(\mathrm{n}<30)$ (Table 4): for procedural learning variables (non-parametric distribution), the $\mathrm{U}$ test of Mann-Whitney for independent samples, while for the variable satisfaction (parametric) the Student's T-Test was used for independent samples.

\section{Table 4}

Results of the Shapiro-Wilk normality test for continuous variables

\begin{tabular}{|l|l|c|c|c|}
\hline \multicolumn{2}{|c|}{ Continuous variables } & Statistics & Df. & Sig. \\
\hline \multirow{3}{*}{$\begin{array}{l}\text { Procedural } \\
\text { learning }\end{array}$} & Mapping & .747 & 24 & .000 \\
\cline { 2 - 5 } & Notebook & .752 & 24 & .000 \\
\cline { 2 - 5 } & Teaching proposal & .545 & 24 & .000 \\
\cline { 2 - 5 } & Dossier's Average & .879 & 24 & .008 \\
\hline \multicolumn{2}{|l|}{ Satisfaction } & .907 & 14 & .144 \\
\hline
\end{tabular}

\section{Results}

\section{III.1. Procedural learning in the acquisition of geohistorical, linguistic and didactic competencies}

The didactic effectiveness of the itinerary at procedural level (SO3) is manifested through the score given to the tasks of the Dossier of activities, on a scale from 0 to 10 (Figure 2), which yields a high mean (8.8) and range between high values $(7: 10)$. The task with the highest average score was the marking of the itinerary on the map (9.0), with most of the students having obtained a score between 8 and 10 . The completion of the practical activities was the task with the lowest average score (8.5), but it is still a high value, with a greater variability than the rest of the tasks. The teaching proposal has

${ }^{46}$ Eudaldo Enrique Espinoza, "Variables and their operationalization in educational research. Part I,” Conrado. Revista Pedagógica de la Universidad de Cienfuegos 14, no. 65 (2018): 36-46. 
very high values with an average of 8.8 , tightly clustered but with several extreme values. Disaggregated data are not shown between students from a bilingual group and those from a non-bilingual group because no statistically significant differences have been observed between them for any of the variables (Table 5).

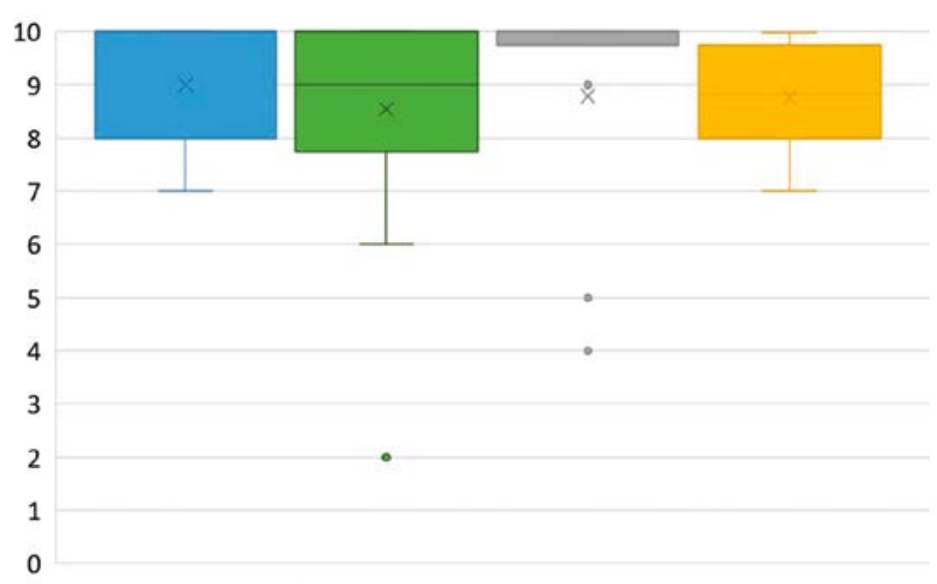

Mapping $\square$ Notebook $\square$ Teaching proposal $\square$ Average

Figure 2

Scoring of the tasks in the dossier of activities, as the procedural learning variables (mark the itinerary over the map, resolve the exercises in the notebook, design a fieldtrip teaching proposal, and average score)

\section{Table 5}

Results of the contrasts of hypothesis of statistically significant differences ( $p$-value $<.05$ ) between the procedural learning variables and the variable "bilingual"

\begin{tabular}{|l|c|}
\hline \multicolumn{1}{|c|}{ Variables } & Sig. \\
\hline Mapping & .147 \\
\hline Notebook & .065 \\
\hline Teaching proposal & .951 \\
\hline Dossier's Average & .099 \\
\hline
\end{tabular}




\section{III.2. Consolidated comprehensive learning after the acquisition of geohistorical, linguistic and didactic competencies}

The didactic effectiveness of the itinerary from a comprehensive learning approach ( $\mathrm{SO} 4)$ has been determined by contrasting the percentage of students who have demonstrated correct knowledge in the post-test with those of the pre-test (Figure 3). It is observed that, prior to the activity, almost $50 \%$ of the students had average correct knowledge, while, posteriori, $71.5 \%$ of the students have such knowledge, which represents an increase of $24.5 \%$. A greater number of students showed improvement in linguistic competency, from an adequate prior knowledge of very few students $(32.3 \%)$ to an increase of $26.4 \%$ of students with satisfactory later knowledge. Geohistorical competencies are the ones that the most participants had acquired before the activity (61.8\%), but even so, $22.6 \%$ more managed to develop them after its completion.

These noticeable differences between later and prior knowledge are statistically significant in all variables (Table 6). Disaggregated data are not shown between students from a bilingual group and those from a nonbilingual group because, in this case, no statistically significant differences have been observed between them for any of the variables (Table 7).

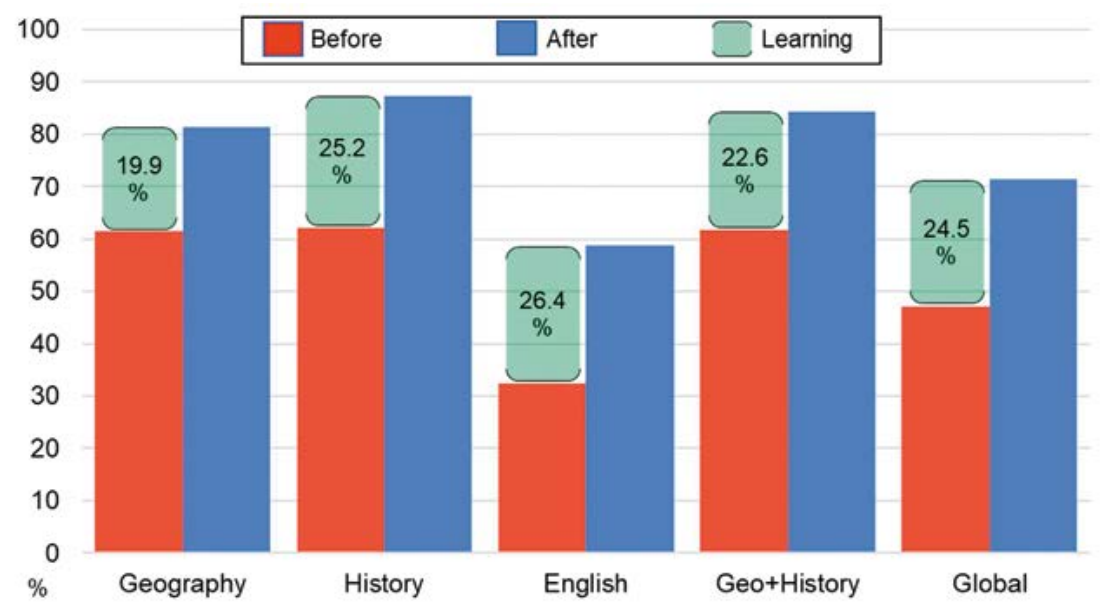

Figure 3

Percentage of students with correct knowledge of the comprehensive learning variables 


\section{Table 6}

Results of the contrasts of hypothesis of statistically significant differences ( $p$-value $<.05$ ) between the comprehensive learning variables before and after carrying out the activity (related samples)

\begin{tabular}{|l|c|c|}
\hline \multicolumn{1}{|c|}{ Variables } & $\mathrm{Z}$ & Asymptotic Sig. (bilateral/2-tailed) \\
\hline Geography & -2.342 & .019 \\
\hline History & -3.075 & .002 \\
\hline English & -2.695 & .007 \\
\hline Geo + History & -3.195 & .001 \\
\hline Global & -3.111 & .002 \\
\hline
\end{tabular}

Table 7

Results of the contrasts of hypothesis of statistically significant differences between the comprehensive learning variables and the variable "bilingual"

\begin{tabular}{|c|c|c|c|c|c|c|}
\hline Phase & Variables & $\begin{array}{c}\text { Mann- } \\
\text { Whitney U }\end{array}$ & $\begin{array}{l}\text { Wilcoxon's } \\
\text { W }\end{array}$ & z & $\begin{array}{l}\text { Asymptotic } \\
\text { Sig. } \\
\text { (bilateral) }\end{array}$ & $\begin{array}{l}\text { Exact sig. } \\
{[2 \text { * (one- }} \\
\text { sided sig.)] }\end{array}$ \\
\hline \multirow{5}{*}{ Before } & Geography & 57 & 102 & -1.274 & .203 & .232 \\
\hline & History & 53.5 & 224.5 & -1.45 & .147 & .160 \\
\hline & English & 54 & 99 & -1.396 & .163 & .176 \\
\hline & Geo + History & 74.5 & 245.5 & -.339 & .735 & .743 \\
\hline & Global & 45 & 90 & -1.854 & .064 & .067 \\
\hline \multirow{5}{*}{ After } & Geography & 9 & 12 & -.429 & .668 & .769 \\
\hline & History & 10 & 76 & -.206 & .837 & .923 \\
\hline & English & 4 & 70 & -1.395 & .163 & .231 \\
\hline & Geo + History & 6.5 & 9.5 & -.922 & .357 & .410 \\
\hline & Global & 10 & 76 & -.198 & .843 & .923 \\
\hline \multirow{5}{*}{$\begin{array}{l}\text { After- } \\
\text { Before }\end{array}$} & Geography & 8 & 74 & -.618 & .536 & .641 \\
\hline & History & 6 & 9 & -1.005 & .315 & .410 \\
\hline & English & 7.5 & 73.5 & -.693 & .488 & .513 \\
\hline & Geo + History & 10.5 & 13.5 & -.101 & .92 & .923 \\
\hline & Global & 11 & 77 & 0 & 1 & 1.000 \\
\hline
\end{tabular}




\section{III.3. Student assessment on the acquisition of geohistorical, linguistic and didactic competencies}

Without knowing the assessment of their learning and based exclusively on their lived experience with the workshop, the students give a very high average score (SO5): $4.5 \pm 0.7$ in a 1:5 range, based on the score of a variety of items of satisfaction (Figure 4). The best valued items $(4.7 \pm 0.5)$ are related to the acquisition of greater sensitivity towards urban heritage. The least valued, though with average values that remain

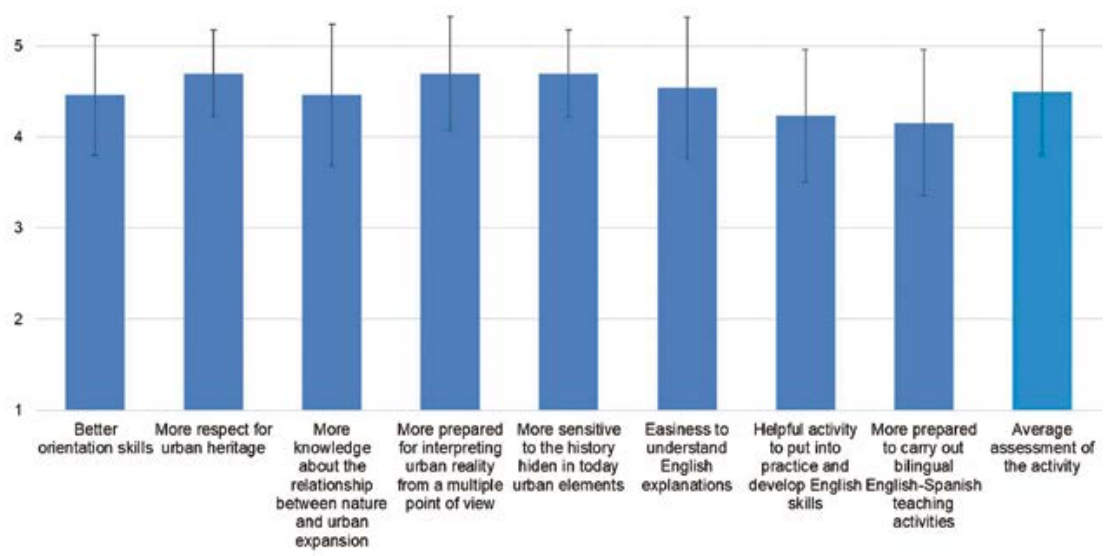

Figure 4

Average rating and standard deviation of the students' satisfaction items after carrying out the activity

Table 8

Results of the contrasts of hypothesis of statistically significant differences between the variable satisfaction and the "bilingual" variable

\begin{tabular}{|l|c|c|c|c|c|}
\hline \multirow{2}{*}{ Equal variances } & \multicolumn{3}{|c|}{ Levene's test of equal variances } & \multicolumn{3}{|c|}{ T-test comparing means } \\
\cline { 2 - 6 } & $\mathrm{F}$ & $\mathrm{Sig}$. & $\mathrm{t}$ & $\mathrm{Gf}$ & Sig. (bilateral) \\
\hline Assumed & 3.216 & .098 & .670 & 12 & .516 \\
\hline Not assumed & & & 1.141 & 11.175 & .278 \\
\hline
\end{tabular}


high (4.2), are those related to the implementation of bilingual teaching. No disaggregated data are shown between students from a bilingual group and those from a non-bilingual group because no statistically significant differences have been observed between them for the satisfaction variable (Table 8).

Finally, from the open opinions of the students about the workshop, a higher frequency of mentions of positive than negative aspects is observed (Figure 5). This review highlighted that more than half of the students believe that the activity is interesting and pleasant. 38.5\% value their contribution to learning Geography and History in a practical way. 23.1\% consider that it is very useful for teaching Social Sciences and English. There are only two types of negative opinions, relative to the duration, considered excessive by $23.1 \%$ of the students, and to the involvement of the students, which $15.4 \%$ remark as insufficient.

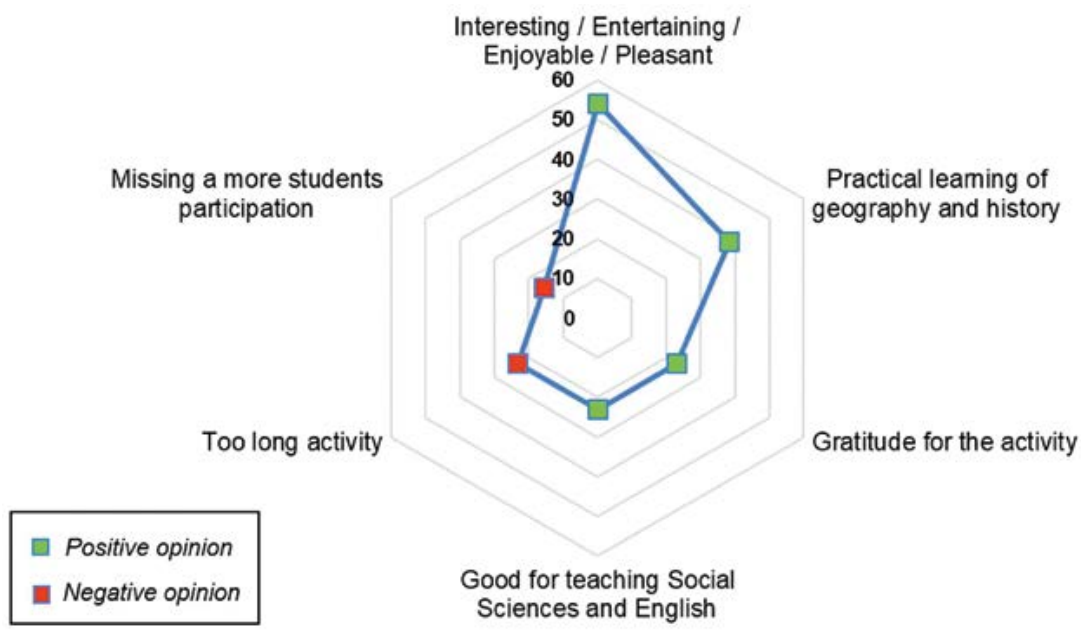

Figure 5

Categories of open opinions about the activity and percentage of students who submit them

\section{Discussion}

The results confirm the main idea of the scientific literature that a didactically planned fieldtrip, such as the urban itinerary (SO1), can promote the learning of participants through the development of 
competencies..$^{47,48,49}$ This has been verified here both from a procedural point of view during the course of the itinerary and from a point of view of comprehensive learning after its completion $(R Q 2$ and $R Q 3)$.

The competencies that have been assessed in this work are geographical, historical, linguistic and didactic ( $R Q 1, S O 2$ and SO3). Geographic competencies are those that are most clearly acquired in a didactic itinerary, ${ }^{50,51}$ by its own definition as a journey through a space, which must be completed by applying skills of location, orientation, cartographic interpretation, recognition of territorial landmarks, etc. In this itinerary, based on the teaching explanations during the trip, all participants are able to draw the route reliably on an urban map of Cartagena that has been followed. Other studies also confirm this geographic learning based on cartographic management, ${ }^{52,53}$ which is present in all geographical tuning projects. ${ }^{54}$

The acquisition of historical competencies is very clear in the resolution of the practical activities proposed at each stop, where the participants know how to rigorously relate geographical factors and historical events. Although these exercises are assessed with slightly lower values than those of the geographical route, probably due to their greater complexity and therefore difficulty, the results are still high. The use of didactic fieldtrips to make geography-history relationships explicit is frequent in the scientific literature and also presents good learning results. ${ }^{55}$

These geographical, historical, and combined competencies can also be developed in a consolidated learning process ( $\mathrm{SO} 4$ ), with students recognizing

${ }^{47}$ Faith Tucker and John Horton, “'The show must go on!' Fieldwork, mental health and wellbeing in Geography, Earth and Environmental Sciences,” Area 51, no. 1 (2019): 84-93.

48 Anttoni Kervinen, Anna Uitto, and Kalle Juuti, "How fieldwork-oriented biology teachers establish formal outdoor education practices," Journal of Biological Education 54, no. 2 (2020): 115-28.

49 Trevor H.B. Sofield and Lawal Mohammed Marafa, "Revitalizing fieldtrips in tourism: Visual anthropology, photo elicitation, rapid appraisal, participant observation and Habermas," Tourism Management 75 (2019): 522-46.

${ }^{50}$ Silvia Aparecida Sousa Fernandes, et al., "Educación geográfica," 1-22.

${ }^{51}$ Amy Richmond Krakowka, "Field Trips as Valuable Learning Experiences in Geography Courses,” Journal of Geography 111, no. 6 (2012): 236-44.

52 Carlos Martínez-Hernández and Claudia Yubero, "Explaining urban”, 67.

${ }^{53}$ Christian Schott, "Virtual fieldtrips and climate change education for tourism students," Journal of Hospitality, Leisure, Sport and Tourism Education 21 (2017): 13-22.

${ }^{54}$ Karl Donert, Aspects of the State of Geography in European higher education. TUNING Geography: a report of findings and outcomes (Liverpool: Herodot Network, 2007).

${ }^{55}$ Helena Pinto, and Jaqueline Zarbato, "Constructing a significant learning through local heritage: Practicing heritage education in Portugal and Brazil," Estudios Pedagógicos 43, no. 4 (2017): 203-27. 
historical events and milestones and geographical factors in the urban development of the city where it has taken place after completion of the activity (SO2). The geographical and historical knowledge of the city was already high before carrying out the activity, probably because it was the urban center of vital reference for the participants, ${ }^{56}$ but after the itinerary the knowledge is extended to many more participants. It seems that the itinerary has contributed to developing long-term geohistorical skills, not only applied at the time of the outing but also significant and consolidated. This represents a great didactic milestone, recently sought in numerous educational practices in the didactics of social sciences..$^{57,58}$

From the point of view of long-term learning, didactic fieldtrips have shown to be more successful in emotional issues than in disciplinary matters. ${ }^{59}$ The key to making this itinerary a good practice for consolidated disciplinary learning, without giving up the emotional benefit, may lie in its structuring based on an explicit and well-sequenced geohistorical context, without which the route loses its temporal-space meaning. Therefore, any memory of the itinerary also entails a review of the context.

When a didactic fieldtrip is carried out with teachers in training, it is not limited to being conceived as a strategy to transmit knowledge, but also becomes knowledge in itself. ${ }^{60,61}$ One of the tasks of the itinerary is the submission of a didactic proposal to teach social sciences through fieldwork precisely to develop didactic skills among the participants (SO3). The result is very positive, since in a generalized way proposals are designed that adequately promote the development of geohistorical competences, presenting a rigorous teaching planning. One of the didactic strengths of fieldtrips, very relevant to teacher training, is the high degree

${ }^{56}$ Daniele T.P. Souza, et al., "Learning in, with, and through the territory: Territory-based learning as a catalyst for urban sustainability," Sustainability 12, no. 7 (2020): 3000.

${ }^{57}$ Subadrah Madhawa Nair and Moganasundari Narayanasamy, "The effects of utilising the concept maps in teaching history," International Journal of Instruction 10, no. 3 (2017): 109-26.

${ }^{58}$ Edward Jadallah, "Constructivist Learning Experiences for Social Studies Education," The Social Studies 91, no. 5 (2000): 221-25.

${ }_{59}$ Ryan G. Dale et al., "Influence,", 613-31.

${ }^{60}$ Emilio Costillo, Ana Belén Borrachero, et al., "Contributions of the nature field trips as teaching and learning activities in the opinion of the prospective teachers," Indagatio didáctica 6, no. 3 (2014): 10-22.

${ }^{61}$ Bryan Rebar, and Larry Enochs, "Integrating Environmental Education Field Trip Pedagogy into Science Teacher Preparation," In The Inclusion of Environmental Education in Science Teacher Education, ed. Alec Bodzin, Beth Shiner Klein, and Starlin Weaver (Dordrecht: Springer, 2010), 111-26. 
of transfer they generate ${ }^{62}$ due to the teacher imitation technique. This effect may also be heightened when the activity is well structured and sequenced.

One of the keys to the research approach consisted in the uncertainty of the influence that the vehicular language of the itinerary could exert on the acquisition of skills. Our results show that the combination of the mother tongue (Spanish) with the first curricular foreign language (EFL) has not impeded the development of the geohistorical competencies that are presupposed in well-planned fieldtrips ${ }^{63}$ and didactic competencies in the case of its application with teachers in training. ${ }^{64}$ On the contrary, measurements of the degree of participants' learning produced high values, and the development of a new type of non-habitual competencies in the didactic itineraries has been verified in this demonstration of the potential of incorporating linguistic competencies. During the route, these competencies are continuously developed by the participants, passively and actively, listening to the teaching explanations in English with support in Spanish for the more complex technicalities or expressions, consulting the map in English, reading the activities in both languages and resolving them in English and when raising questions and comments doing so mostly in English. In fact, the assessment of these tasks has taken into account the capacity for linguistic expression and, as previously mentioned, the learning results have been high ( $\mathrm{SO} 2$ and $\mathrm{SO} 3$ ).

The degree of acquisition of linguistic competencies has been more explicitly quantified in the form of consolidated learning (SO4), contrasting the knowledge after carrying out the activity with what previously held. Very few students demonstrated an adequate level of English (according to the standard expected in the design of the activity) before carrying out the itinerary; however, after its completion, almost twice as many were capable of reaching a good level, which was the greatest increase in learning from this exercise. This level is demonstrated in the acquisition of vocabulary and in the ability to understand and express urban events.

There are few similar experiences for the development of language competencies. In bilingual education, fieldtrips are conceived of more as cultural immersion than as disciplinary learning strategies, which makes

${ }^{62}$ Emilio Costillo et al., "Contributions", 10-22.

${ }^{63}$ Nikos Lambrinos, and Fani Asiklari, "The introduction of GIS and GPS through local history teaching in primary school," European Journal of Geography 5, no. 1 (2014): 32-47.

${ }^{64}$ Bryan Rebar and Larry Enochs, "Integrating”, 111-26. 
them more frequent abroad, ${ }^{65,66,67}$ virtually, ${ }^{68,69}$ in closed and isolated spaces ${ }^{70,71}$ or in non-formal education ${ }^{72}$ than in familiar and formal settings.

Beyond the integral experiences of cultural immersion, we can make a comparison with the research of Papadopoulos \& Griva, which manages to increase the level of language and vehicular culture in immigrant students through trips through the host country ${ }^{73}$ thus as with the work of Montero Pozo \& Jerez García, who design a bilingual environmental itinerary for Erasmus students and aim to achieve results in linguistic and geographical competencies at the level of those obtained in our research. ${ }^{74}$ As local experiences, we can highlight the studies of Halloran et al., who also demonstrate an improvement in language learning during a didactic fieldtrip, in this case creative writing on fieldtrips to the natural environment ${ }^{75}$ and Brox, who confirms language learning in a bilingual environmental education experience outside the classroom. ${ }^{76}$

${ }^{65}$ Sean Grant, "Effects", 442-53.

${ }^{66}$ Montserrat Mir, "Teaching”, 230-57.

${ }^{67}$ Beatriz De Diego-Lázaro, Kevin Winn, and María Adelaida Restrepo, "Cultural competence and self-efficacy after study abroad experiences," American Journal of SpeechLanguage Pathology 29, no. 4 (2020): 1896-909.

${ }_{68}$ Benjamin Chang, et al., "Foreign language".

${ }^{69}$ N. Eleni Pappamihiel, and Jennifer Hatch Knight, "Using digital”, 276-80.

${ }^{70}$ Fabiana Fazzi, and David Lasagabaster, "Learning beyond the classroom: Students' attitudes towards the integration of CLIL and museum-based pedagogies," Innovation in Language Learning and Teaching 15, no. 2 (2021): 156-68.

71 Johanna M. Tigert and Sheila Kirschbaum, "How Museum Teachers Scaffold Emergent Bilingual Learners' Meaning-making During Field Trips," Journal of Museum Education 44, no. 4 (2019): 439-47.

${ }^{72}$ Haim Eshach, "Bridging In-school and Out-of-school Learning: Formal, NonFormal, and Informal Education," Journal of Science Education and Technology 16, no. 2 (2007): 171-90.

${ }^{73}$ Isaak Papadopoulos, and Eleni Griva, "Learning in the Traces of Greek Culture": A CLIL Project for Raising Cultural Awareness and Developing L2 Skills," International Journal of Learning, Teaching and Educational Research 8, no. 1 (2014): 76-92.

${ }^{74}$ Jonathan Montero Pozo, and Óscar Jerez García, "The Teaching Itinerary as a Resource for Development of Communication Competences: Design of a Bilingual App," in La competencia lingüística en la comunicación: visiones multidisciplinares y transversalidad, ed. José Vicente Salido López and Pedro Vicente Salido López (Cuenca: Ediciones de la Universidad de Castilla-La Mancha, 2019), 199-207.

75 John Halloran, et al., "The literacy fieldtrip: Using UbiComp to support children's creative writing (paper presented at the Proceeding of the 2006 Conference on Interaction Design and Children, Tampere, Finland, June 2006), 17-24.

76 Ali Brox, "Notes from the Field: Course Design and Instruction Strategies in Environmental Studies classes for Bilingual Student," Issues in Language Instruction at the Applied English Center 4, no. 1 (2015): 9-11. 
However, it is striking from our research that, despite the increase in learning, a few students did not achieve the adequate level in EFL, while learning in geohistorical competencies was more generalized. It may be that linguistic competencies are the most difficult to develop of those studied, perhaps due to lack of sufficient prior knowledge in urban semantic fields, because of little habit of approaching urban reality in another language, or due to the very nature of language learning, more linked to a process of cognitive change than a specific change in knowledge. Among the few didactic fieldtrips in familiar environments to develop linguistic competencies in formal education, the one studied by Tigert \& Kirschbaum coincides in highlighting the difficulty of language learning in very limited contexts. ${ }^{77}$

Regarding linguistic competencies, it could be expected that students with more training in EFL (coming from a bilingual training group) would reach a level of knowledge significantly higher than the rest (belonging to non-bilingual groups), especially prior to the itinerary, as happens in the CLIL experiences ${ }^{78}$ However, there have been no statistically significant differences in the degree of acquisition of any competency or assessment and in any phase of the evaluation procedure $(R Q 4)$. This may be due to a bias in the students, since participation in the itinerary was voluntary, which could be interpreted as an offer of supplementary training especially aimed at students interested in linguistic competencies who may come from both nonbilingual groups with linguistic concerns as well as bilingual groups with extra training needs. These circumstances may have equalized the level of linguistic competency prior to completing the itinerary.

In any case, the itinerary of our research has led to the development of all the competencies studied, including linguistic ones. In this case, the differences between the knowledge demonstrated after its completion and the previous one, in any of the competencies, are statistically significant $(R Q 3)$. This gives more value to the verified learning and reinforces the idea that a didactic fieldtrip can be a very valid interdisciplinary teaching / learning strategy in the paradigm of competency education, in line with studies on didactic fieldtrips that highlight its valuable role in integral learning, ${ }^{79,80}$ although not all improvements recorded were significant. The main implication of these results is that didactic fieldtrips can be part of CLIL

77 Johanna M. Tigert and Sheila Kirschbaum, "How Museum”, 171-90.

${ }^{78}$ Dieter Wolff, "Integrating language and content in the language classroom: Are transfer of knowledge and of language ensured?," ASp 41/42 (2003): 35-46.

79 José Manuel Crespo et al., “An approach”, 121-40.

${ }^{80}$ Jennifer DeWitt, and Martin Storksdieck, "A short review of school field trips: Key findings from the past and implications for the future," Visitor Studies 11, no. 2 (2008): 181-97. 
programs, by allowing content to be worked through what Cristóbal-Aragón \& Greca define as authentic learning contexts with an active role of the students and based on cooperation, ${ }^{81}$ despite the fact that there is hardly any scientific literature on this relationship between didactic fieldtrips and bilingual education. ${ }^{82}$

The students themselves are aware of the importance of the itinerary in their competency training (SO5), highlighting above all three great achievements: (i) their learning in geographical skills, as is usual in this type of experiences; ${ }^{83}$ (ii) the development of historical thinking and heritage awareness, a recent concern in the didactics of social sciences and which is being observed to have been significantly enhanced in recent years compared to traditional, imminently passive and rote historical learning; $; 4,85,86$ and (iii) contact with bilingual educational practices of comprehensive training to take as references, in the face of the current conflict around bilingual education due to the fear that advanced linguistic training will happen at the cost of non-linguistic training. ${ }^{87,88}$

Finally, the students highlight a dimension of the didactic fieldtrips widely verified in the scientific literature but no less important: its contribution to increasing motivation, ${ }^{89,90,91}$ as a result of a playful and pleasant conception of the itinerary carried out $(R Q 5)$. There are only two aspects that can be

${ }^{81}$ Esther Cristóbal-Aragón and Ileana M. Greca, "Science", 31-47.

${ }^{82}$ Isaak Papadopoulos, and Eleni Griva, "Learning", 76-92.

${ }^{83}$ David H. Uttal, et al., "The Malleability of Spatial Skills: A Meta-Analysis of Training Studies", Psychological Bulletin 139, no. 2 (2013): 352-402.

${ }^{84}$ Cosme Jesús Gómez Carrasco and Pedro Miralles Martínez, "Thinking historically or memorizing the past? assessing historical content in compulsory education in Spain," Revista De Estudios Sociales 52 (2015): 52-68.

${ }^{85}$ Jan Karkdijk, Joop Van Der Schee, and Wilfried Admiraal, "Effects of teaching with mysteries on students geographical thinking skills," International Research in Geographical and Environmental Education 22, no. 3 (2013): 183-90.

${ }^{86}$ Bruce A. VanSledright, The challenge of rethinking history education: On practices, theories, and policy (New York and London: Routledge, 2011).

${ }^{87}$ Dominik Rumlich, "Bilingual education in monolingual contexts: a comparative perspective," The Language Learning Journal 48, no. 1 (2020): 115-9.

88 Jasone Cenoz, et al., "Critical," 243-262.

89 Alan Marvell, and David Simm, "Emotional geographies experienced during international fieldwork: An evaluation of teaching and learning strategies for reflective assessment," Journal of Geography in Higher Education 42, no. 4 (2018): 515-30.

${ }^{90}$ Marc Stern, Robert Powell, and Nicole Ardoin, "What Difference Does It Make? Assessing Outcomes from Participation in a Residential Environmental Education Program," The Journal of Environmental Education 39, no. 4 (2008): 31-43.

${ }_{91}$ James Farmer, et al., "An Elementary," 33-42. 
improved in the opinion of the students: the excessive duration of the itinerary, which left them arriving exhausted to the last tasks, and the limited opportunities they felt they were afforded for participation and interaction throughout the trip. This last perception does not fit with their true participation, adequate in all tasks, possibly highlighting a natural fear of making a mistake when speaking in public in another language, which generates anxiety and persuades them to participate orally more than they would like. It is a common problem in the teaching of foreign languages ${ }^{92}$ specifically that bilingual educational practices can reduce anxiety ${ }^{93}$ with the confidence provided by the possibility of resorting to the mother tongue, ${ }^{94}$ so perhaps more focus should be placed on this confidence in future planning and research. One the one hand, there are some activities and tasks that could be carried out to defuse language issues and promote a braver use of language before, during and after the itinerary. For instance, before the fieldtrip, vocabulary related to History and Geography could be exercised by asking students to give the definitions of unknown words or draw pictures of specific objects and locations. During the itinerary, students could be given a checklist to go on a fact-finding mission as they do the walking, writing down their discoveries on their maps. Finally, at the end of the itinerary students could be prompted to share and discuss what they liked, learnt and would recommend to others. Furthermore, as a follow-up activity, students could be asked to pretend to be the ones in charge of the itinerary and record a video showing their favourite location. On the other hand, some items about emotional issues could be included in the research questionnaire for future experiences, in order to detect when and how students feel afraid of using language, so that we can effectively respond to their concerns.

\section{Conclusions}

The results have made it possible to answer the main research question on the viability of a bilingual didactic fieldtrip with teachers in training that maintains the development of geohistorical and didactic competences typical

92 Nurhayati Ghazali, Nur Ehsan Mohd Said, and Tan Kim Hua, "Understanding second language anxiety: Feedback from ESL learners in TVET," Universal Journal of Educational Research 8, no. 5 (2020): 2057-63.

${ }_{93}$ María Del Pozo Beamud, "Affective variables and bilingual education: a quantitative study," ENSAYOS, Revista de la Facultad de Educación de Albacete 35, no. 2 (2020): 151-69.

${ }^{94}$ Jijia Zhang, et al., "The effects of foreign language anxiety, nervousness and cognitive load on foreign language lying: Evidence from Chinese-English bilinguals," Acta Psychologica Sinica 52, no.7 (2020): 861-73. 
of the fieldtrips in the area of social sciences, as well as incorporating the scope of linguistic competences $(G O)$. The hypothesis, therefore, that a didactic fieldtrip with CLIL philosophy is a teaching possibility has been confirmed. Specifically, the design of an urban itinerary in the Spanish city of Cartagena has been presented, through five stops representing moments of local historical import, where the participants had to solve a series of tasks mobilizing geohistorical, didactic and linguistic competencies. The teaching staff guided and the participants had to interact, always in the foreign language of training (English) with specific support in the mother tongue (Spanish).

Fulfilling the general objective of the research, the didactic effectiveness of this itinerary has been assessed, distinguishing between participants from bilingual and non-bilingual training groups. To do this, a procedural learning evaluation system has been established during the itinerary and consolidated after the itinerary, resorting to the teaching evaluation of a dossier of activities carried out by the participants and a questionnaire in two phases (before and after the itinerary) through a pre-test and a post-test about the level of knowledge of geohistorical and linguistic aspects of the fieldtrip, adding a student assessment in the last questionnaire. The data have been analysed from descriptive and inferential statistics.

The evaluation of the didactic effectiveness has resulted in very high values of development of geohistorical, didactic and linguistic competencies in procedural tasks during the itinerary, as well as a high increase in the consolidated acquisition of these competencies after completing the itinerary. The greatest growth has been observed precisely in language skills, although it is true that it started from a lower initial level of development than the other skills. The level of knowledge after the itinerary was significantly higher than before, for all competencies (RQ3). However, in no case either during the itinerary and after its completion were statistically significant differences observed based on membership in a bilingual training group (RQ4). This degree and this form of didactic effectiveness confirm the viability of an itinerary for the development of the aforementioned competencies ( $R Q 1$ and $R Q 2)$. The students themselves validate this idea by highly valuing the usefulness of the itinerary in their training (RQ5), highlighting, within a framework of playful motivation, their improvement in geohistorical skills and awareness and a perception of a teaching reference for bilingual teaching.

These results reinforce the idea that urban itineraries and educational fieldtrips in general promote interdisciplinary learning and strengthen the acquisition of skills that may remain incomplete with only classroom-based instruction. For this reason, it seems reasonable to claim that didactic 
fieldtrips should have a greater presence in teacher training, preferably in a curricular way (either through the contents of different subjects or through competencies related to them). This will also have an impact on the transposition that the teachers in training will make with their future primary education students, in whom they will instil the importance of leaving the classroom and, consequently, a holistic knowledge of the environment and greater awareness of heritage.

There are already many studies on experiences of fieldtrips in higher education in the educational area, in a variety of environments. The one that presented in this research, however, in the form of an itinerary in an urban space, has the peculiarity that it has allowed us to incorporate linguistic competencies typical of bilingual education and geohistorical and didactic competencies typical of social sciences. This integrated learning gives the green light to didactic fieldtrips as CLIL method strategies, taking the joint learning of contents and languages outside the classroom, in line with current competencies programmes and tuning projects.

Furthermore, the development of these competencies has followed deep didactic trends, such as: the search for meaningful learning, starting from a local environment; the acquisition of historical thinking and heritage awareness through the critical relationship of geohistorical considerations; and the generation of a climate of trust to mitigate the initial fear of a foreign language student regarding its interactive oral use, due to the possibility of using the mother tongue promptly, maintaining a pseudoimmersive environment that is also pleasant. With these features integrated, there are hardly any experiences of didactic fieldtrips in the scientific literature.

Finally, some limitations of our study should be borne in mind which may mitigate the validity of the quantitative results, although the statistical validations carried out may compensate for them in some way. For example, the sample was of a small size and the exercise was unique, which makes an exact comparison with other fieldtrips impossible. We must also take into account the inevitable halo of subjectivity that can escape in the assessment of a part of the evaluation instruments, as well as the possible bias in the selection of participants because it is a voluntary activity that can bring together students with homogeneous didactic expectations, making inferential statistical analyses difficult. This voluntary nature also produces a certain bias in that not all participants complete the entire evaluation process, and therefore the research does not have data from less diligent students. In successive investigations, the study sample could be increased and extended to include multiple urban itineraries. 


\section{Bibliography}

Abello-Contesse, Christian. "Bilingual and multilingual education: An overview of the field." In Bilingual and multilingual education in the 21 st century: Building on experience, edited by Christian Abello-Contesse et al., 3-23. Bristol: Multilingual Matters, 2013.

Aguilera, David. "Field trip as a didactic resource to teach sciences. A systematic review," Revista Eureka sobre Enseñanza y Divulgación de las Ciencias 15, no. 3 (2018): 3103-19. https://doi.org/10.25267/Rev_Eureka_ensen_divulg_ cienc.2018.v15.i3.3103

Benejam, Pilar. "The aims of fieldtrips," Iber: Didáctica de las ciencias sociales, geografía e historia 36 (2003): 7-12. http://hdl.handle.net/11162/88171

Bergan, Sjur. "The European Higher Education Area: A road to the future or at way's end?" Tuning Journal for Higher Education 6, no. 2 (2019): 23-49. http://dx.doi. org/10.18543/tjhe-6(2)-2019pp23-49

Biedermann, Anne. "Linguistic mediation in a foreign language teaching context," Synergies Chili 10 (2014): 83-91. https://gerflint.fr/Base/Chili10/biedermann.pdf

Brox, Ali. "Notes from the Field: Course Design and Instruction Strategies in Environmental Studies classes for Bilingual Student," Issues in Language Instruction at the Applied English Center 4, no. 1 (2015): 9-11. https://doi. org/10.17161/ili.v4i1.7005

Cenoz, Jasone, Fred Genesee, and Durk Gorter. "Critical analysis of CLIL: Taking stock and looking forward," Applied Linguistics 35, no. 3 (2014): 243-262. https://doi.org/10.1093/applin/amt011

Chabot, Samuel, Jaimie Drozdal, Yalun Zhou, Hui Su, and Jonas Braasch. "Language learning in a cognitive and immersive environment using contextualized panoramic imagery." In HCI International 2019 - Posters. HCII 2019. Communications in Computer and Information Science, 1034, edited by Constantine Stephanidis, 2029. Cham: Springer, 2019. https://doi.org/10.1007/978-3-030-23525-3_26

Chang, Benjamin, Lee Sheldon, Mei Si, and Anton Hand. 2012. "Foreign language learning in immersive virtual environments." Paper presented at the Proceedings of SPIE - the International Society for Optical Engineering 8289, Burlingame (California), 8 February 2012. https://doi.org/10.1117/12.909835

Cook, Thomas D., Donald T. Campbell, and Laura Peracchio. "Quasi experimentation." In Handbook of industrial and organizational psychology, edited by Marvin D. Dunnette and Leaetta M. Hough, 491-576. Sunnyvale: Consulting Psychologists Press, 1990.

Costillo, Emilio, Ana Belén Borrachero, María Rocío Esteban, and Jesús SánchezMartín. "Contributions of the nature field trips as teaching and learning activities in the opinion of the prospective teachers," Indagatio didáctica 6, no. 3 (2014): 10-22. https://doi.org/10.34624/id.v6i3.3983

Council for Learning Outside the Classroom. Learning Outside the Classroom. Manifesto. Nottingham: DfES Publications, 2006. https://www.lotc.org.uk/wpcontent/uploads/2011/03/G1 .-LOtC-Manifesto.pdf 
Coyle, Do. "Content and Language Integrated Learning: Towards a Connected Research Agenda for CLIL Pedagogies," The International Journal of Bilingual Education and Bilingualism, 10, no. 5 (2007): 543-62. https://doi.org/10.2167/beb459.0

Crespo, José Manuel., María Luisa Gómez, and Luis Alfonso Cruz. “An approach to the National Parks landscapes and educational itineraries," Espacio, Tiempo y Forma 11 (2018): 121-40. https://doi.org/10.5944/etfvi.11.2018.22359

Cristóbal-Aragón, Esther and Ileana M. Greca. "Science teaching in a bilingual context: proposal for teaching an Astronomy content," Revista de Enseñanza de la Física, 30, no. 2 (2018): 31-47. https://revistas.unc.edu.ar/index.php/ revistaEF/article/view/22734/22344

Dale, Liz and Rosie Tanner. CLIL Activities: A resource for subject and language teachers. Cambridge: Cambridge University Press, 2012.

Dale, Ryan G., Robert B. Powell, Marc J. Stern, and Barry A. Garst. "Influence of the natural setting on environmental education outcomes," Environmental Education Research 26, no. 5 (2020): 613-31. https://doi.org/10.1080/13504622.2020.1738346

De Diego-Lázaro, Beatriz, Kevin Winn, and María Adelaida Restrepo. "Cultural competence and self-efficacy after study abroad experiences," American Journal of Speech-Language Pathology 29, no. 4 (2020): 1896-909. https://doi. org/10.1044/2020_AJSLP-19-00101

Del Pozo Beamud, María. "Affective variables and bilingual education: a quantitative study," ENSAYOS, Revista de la Facultad de Educación de Albacete 35, no. 2 (2020): 151-69. https://doi.org/10.18239/ensayos.v35i2.2471

DeWitt, Jennifer and Martin Storksdieck. "A short review of school field trips: Key findings from the past and implications for the future," Visitor Studies 11, no. 2 (2008): 181-97. https://doi.org/10.1080/10645570802355562

Doiz, Aintzane, David Lasagabaster, and Juan Manuel Sierra. "CLIL and motivation: The effect of individual and contextual variables," The Language Learning Journal 42, no. 2 (2014): 209-24. https://doi.org/10.1080/09571736.2014.889508

Domínguez Almansa, Andrés and Ramón Vicente López Facal. "Heritage, landscape and education: initial teacher education and civic education of pupils in primary," CLIO. History and History teaching 40 (2014): 1-26. http://hdl.handle. net/10347/20248

Donert, Karl. Aspects of the State of Geography in European higher education. TUNING Geography: a report of findings and outcomes. Liverpool: Herodot Network, 2007. http://tuningacademy.org/wp-content/uploads/2014/02/ HERODOT_Tuning-Geography.pdf

Eshach, Haim. "Bridging In-school and Out-of-school Learning: Formal, NonFormal, and Informal Education," Journal of Science Education and Technology 16, no. 2 (2007): 171-90. https://doi.org/10.1007/s10956-006-9027-1

Espinoza, Eudaldo Enrique. "Variables and their operationalization in educational research. Part I," Conrado. Revista Pedagógica de la Universidad de Cienfuegos 14, no. 65 (2018): 36-46. https://conrado.ucf.edu.cu/index.php/conrado/article/view/814

Farmer, James, Doug Knapp, and Gregory M. Benton. "An Elementary School Environmental Education Field Trip: Long-Term Effects on Ecological and 
Environmental Knowledge and Attitude Development," The Journal of Environmental Education 38, no. 3 (2007): 33-42. https://doi.org/10.3200/ JOEE.38.3.33-42

Fazzi, Fabiana and Dvaid Lasagabaster. "Learning beyond the classroom: Students' attitudes towards the integration of CLIL and museum-based pedagogies," Innovation in Language Learning and Teaching 15, no. 2 (2021): 156-68. https://doi.org/10.1080/17501229.2020.1714630

Fombona, Javier and María Ángeles Pascual. Adult education, approach based on the analysis of European good practices. Revista Complutense de Educación 30, no. 2 (2019): 647-65. https://doi.org/10.5209/RCED.58882

Freire, Paulo. Political nature of Education: culture, power and liberation [La naturaleza política de la Educación: Cultura, Poder y Liberación]. Barcelona: Paidos-MEC, 1990.

Ghazali, Nurhayati, Nur Ehsan Mohd Said, and Tan Kim, Hua. "Understanding second language anxiety: Feedback from ESL learners in TVET," Universal Journal of Educational Research 8, no. 5 (2020): 2057-63. https://doi. org/10.13189/ujer.2020.080543

Gómez Carrasco, Cosme Jesús and Pedro Miralles Martínez. "Thinking historically or memorizing the past? assessing historical content in compulsory education in Spain," Revista De Estudios Sociales 52 (2015): 52-68. https://doi.org/10.7440/ res52.2015.04

Granero-Gallegos, Antonio and Antonio Baena-Extremera. Physical activities in natural areas: Theory and practice for Physical Education [Actividades fisicas en el medio natural: Teoría y práctica para la Educación Física]. Sevilla: Wanceulen, 2010.

Grant, Sean. "Effects of intensive EFL immersion programmes on willingness to communicate,” Language Learning Journal 48, no. 4 (2020): 442-53. https://doi. org/10.1080/09571736.2017.1422274

Halász, Gábor and Alain Michel. "Key Competences in Europe: interpretation, policy formulation and implementation," European Journal of Education, Research, Development and Policy 46, no. 3 (2011): 289-306. https://doi. org/10.1111/j.1465-3435.2011.01491.x

Halloran, John, Eva Hornecker, Geraldine Fitzpatrick, Mark Weal, David Millard, Danius Michaelides, Don Cruickshank, and David De Roure. 2006. "The literacy fieldtrip: Using UbiComp to support children's creative writing. Paper presented at the Proceeding of the 2006 Conference on Interaction Design and Children, Tampere (Finland), June 2006, 17-24. https://doi.org/10.1145/1139073.1139083

Jadallah, Edward. "Constructivist Learning Experiences for Social Studies Education," The Social Studies 91, no. 5 (2000): 221-25. https://doi. org/10.1080/00377990009602469

Kallioinen, Outi. "Defining and Comparing Generic Competences in Higher Education," European Educational Research Journal 9, no. 1 (2010): 56-68. https://doi.org/10.2304/eerj.2010.9.1.56 
Karkdijk, Jan, Joop Van Der Schee, and Wilfried Admiraal. "Effects of teaching with mysteries on students geographical thinking skills," International Research in Geographical and Environmental Education 22, no. 3 (2013): 183-90. https:// doi.org/10.1080/10382046.2013.817664

Kervinen, Anttoni, Anna Uitto, and Kalle Juuti. "How fieldwork-oriented biology teachers establish formal outdoor education practices," Journal of Biological Education 54, no. 2 (2020): 115-28. https://doi.org/10.1080/00219266.2018.154 6762

Krakowka, Amy Richmond. "Field Trips as Valuable Learning Experiences in Geography Courses," Journal of Geography 111, no. 6 (2012): 236-44. https:/ doi.org/10.1080/00221341.2012.707674

Lambrinos, Nikos, and Fani Asiklari. "The introduction of GIS and GPS through local history teaching in primary school," European Journal of Geography 5, no. 1 (2014): 32-47. http://www.eurogeographyjournal.eu/articles/2.THE\%20 INTRODUCTION\%20OF\%20GIS\%20AND\%20GPS\%20THROUGH\%20 LOCAL\%20HISTORY\%20TEACHING\%20IN\%20PRIMARY\% 20 SCHOOL-2.pdf

Lavega, Pere, Unai Sáez, Gerard Lasierra, and Cristofol Salas. "Intradisciplinarity and Interdisciplinarity in the acquisition of competencies: a study of a cooperative learning experience," Revista Electrónica Interuniversitaria de Formación del Profesorado 16,no. 1 (2013): 133-45.https://doi.org/10.6018/reifop.16.1.179491

López Facal, Ramón Vicente. "Competencies and social sciences teaching [Competencias y enseñanza de las ciencias sociales]," Íber: Didáctica de las ciencias sociales, geografía e historia 74 (2013): 5-8. https://www.grao.com/es/ producto/competencias-y-ensenanza-de-las-ciencias-sociales

López Salmerón, Emilio José. "The creation of a city: urbanistic evolution of Cartagena [La creación de una ciudad: evolución urbanística de Cartagena]." PhD Dissertation, University of Alicante (Spain), 2017. http://hdl.andle. net/10045/75357

López-Pastor, Víctor Manuel, Miriam Molina, Cristina Pascual, and Juan Carlos Manrique. "The importance of using Formative and Shared Assessment in Physical Education Teacher Education: Tutored Learning Projects as an example of good practice," Retos. Nuevas tendencias en Educación Física, Deporte y Recreación 37 (2020): 620-27. https://doi.org/10.47197/retos.v37i37.74193

López-Pastor, Víctor Manuel. "The rol of formative assessment in competency assessment: contributions from the formative and shared assessment in higher education network," Revista de Docencia Universitaria 9, no. 1 (2011): 159-73. https://doi.org/10.4995/redu.2011.6185

Lumino, Rosaria and Paolo Landri. "Network time for the European Higher Education Area," Philosophy and Theory 52, no. 6 (2020): 653-663. https://doi. org/10.1080/00131857.2019.1708328

Maller, Cecily Jane. "Promoting children's mental, emotional and social health through contact with nature: a model," Health Education 109, no. 6 (2009): 52243. https://doi.org/10.1108/09654280911001185 
Martínez-Hernández, Carlos and Claudia Yubero. "Explaining Urban Sustainability to Teachers in Training through a Geographical Analysis of Tourism Gentrification in Europe," Sustainability 12, no. 1 (2020): 67. http://doi. org/10.3390/su12010067

Marvell, Alan and David Simm. (2018). "Emotional geographies experienced during international fieldwork: An evaluation of teaching and learning strategies for reflective assessment," Journal of Geography in Higher Education 42, no. 4 (2018): 515-30. https://doi.org/10.1080/03098265.2018.1460806

Mir, Montserrat. "Teaching and learning about Spanish L2 compliments in shortterm study abroad," Study Abroad Research in Second Language Acquisition and International Education 5, no. 2 (2020): 230-57. https://doi.org/10.1075/ sar.18004.mir

Mogensen, Finn and Karsten Schnack. "The action competence approach and the 'new' discourses of education for sustainable development, competence and quality criteria," Environmental Education Research 16, no. 1 (2010): 59-74. https://doi.org/10.1080/13504620903504032

Montero Pozo, Jonathan and Óscar Jerez García. “The Teaching Itinerary as a Resource for Development of Communication Competences: Design of a Bilingual App," in La competencia lingüística en la comunicación: visiones multidisciplinares y transversalidad, edited by José Vicente Salido López and Pedro Vicente Salido López, 199-207. Cuenca: Ediciones de la Universidad de Castilla-La Mancha, 2019. http://doi.org/10.18239/jor_19.2019.02

Nair, Subadrah Madhawa and Moganasundari Narayanasamy. "The effects of utilising the concept maps in teaching history," International Journal of Instruction 10, no. 3 (2017): 109-26. https://doi.org/10.12973/iji.2017.1038a

Nashaat-Sobhy, Nashwa and Ana Llinares. "CLIL students' definitions of historical terms," International Journal of Bilingual Education and Bilingualism, in press (2020). https://doi.org/10.1080/13670050.2020.1798868

Pagès, Joan. "Teaching and learning social sciences in 21 st Century [Enseñar y aprender ciencias sociales en el siglo XXI: reflexiones casi al final de una década]." In Investigación en Educación, Pedagogía y Formación Docente: La investigación al servicio de una educación incluyente y de calidad en un mundo diverso y globalizado, edited by several authors, 139-154. Antioquía: Universidad Pedagógica Nacional, Universidad de Antioquía, Corporación Interuniversitaria de Servicios, 2009. http://www.didactica-ciencias-sociales.org/articulos_ archivos/2009-pages-e-a-ccssXXI.pdf

Papadopoulos, Isaak and Eleni Griva. "Learning in the Traces of Greek Culture": A CLIL Project for Raising Cultural Awareness and Developing L2 Skills," International Journal of Learning, Teaching and Educational Research 8, no. 1 (2014): 76-92. http://www.ijlter.org/index.php/ijlter/article/view/168

Pappamihiel, N. Eleni and Jennifer Hatch Knight. "Using digital storytelling as a language experience approach activity: Integrating English language learners into a museum field trip," Childhood Education 92, no. 4 (2016): 276-80. https:// doi.org/10.1080/00094056.2016.1208005 
Peasland, Emma, Dominic Henri, Lesley Morrell, and Graham Scott. "The influence of fieldwork design on student perceptions of skills development during field courses," International Journal of Science Education 41, no. 17 (2019): 236988. https://doi.org/10.1080/09500693.2019.1679906

Pedrinaci, Emilio. "Fieldwork and sciences learning [Trabajo de campo y aprendizaje de las ciencias]," Alambique: Didáctica de las Ciencias Experimentales 71 (2012): 81-9. https://www.grao.com/es/producto/trabajo-de-campo-yaprendizaje-de-las-ciencias

Pinto, Helena and Jaqueline Zarbato. "Constructing a significant learning through local heritage: Practicing heritage education in Portugal and Brazil," Estudios Pedagógicos 43, no. 4 (2017): 203-27. https://doi.org/10.4067/S0718-07052 017000400011

Rebar, Bryan and Larry Enochs. "Integrating Environmental Education Field Trip Pedagogy into Science Teacher Preparation.” In The Inclusion of Environmental Education in Science Teacher Education, edited by Alec Bodzin, Beth Shiner Klein, and Starlin Weaver, 111-26. Dordrecht: Springer, 2010. https://doi. org/10.1007/978-90-481-9222-9_8

Redecker, Christine and Yves Punie. "The future of learning 2025: developing a vision for change," Future Learning 1 (2013): 3-17. http://publications.jrc. ec.europa.eu/repository/handle/JRC85225

Rodríguez, Juan Antonio and Pablo Joel Santana. "The distance between teachers' and students' work in EHEA: A dangerous gap?", Profesorado. Revista de Currículum y Formación de Profesorado 19, no. 3 (2015): 380-404. https:// recyt.fecyt.es/index.php/profesorado/article/view/43665/25574

Rumlich, Dominik. "Bilingual education in monolingual contexts: a comparative perspective," The Language Learning Journal 48, no. 1 (2020): 115-9. https:// doi.org/10.1080/09571736.2019.1696879

Schott, Christian. "Virtual fieldtrips and climate change education for tourism students," Journal of Hospitality, Leisure, Sport and Tourism Education 21 (2017): 13-22. https://doi.org/10.1016/j.jhlste.2017.05.002

Sofield, Trevor H.B. and Lawal Mohammed Marafa. "Revitalizing fieldtrips in tourism: Visual anthropology, photo elicitation, rapid appraisal, participant observation and Habermas," Tourism Management 75 (2019): 522-46. https:// doi.org/10.1016/j.tourman.2019.04.007

Sousa Fernandes, Silvia Aparecida, Diego García Monteagudo and Xosé Manuel Souto González. "Educación geográfica y las salidas de campo como estrategia didáctica: un estudio comparativo desde el Geoforo Iberoamericano," Biblio3W, Revista Bibliográfica de Geografía y Ciencias Sociales 21, no. 1155 (2016): 1-22. http://www.ub.edu/geocrit/b3w-1155.pdf

Souza, Daniele T.P., Eugenia A. Kuhn, Arjen E.J. Wals, and Pedro R. Jacobi. "Learning in, with, and through the territory: Territory-based learning as a catalyst for urban sustainability," Sustainability 12, no. 7 (2020): 3000. https:// doi.org/10.3390/su12073000 
Stern, Marc, Robert Powell and Nicole Ardoin. "What Difference Does It Make? Assessing Outcomes from Participation in a Residential Environmental Education Program," The Journal of Environmental Education 39, no. 4 (2008): 31-43. https//doi.org/10.3200/JOEE.39.4.31-43

Tejada, José. "The alternation of contexts aimed to the acquisition of competencies in complementary settings of higher education: concepts and strategy," Educación XX1 15,no.2(2012): 17-40.https://doi.org/10.5944/educxx1.15.2.125

Tigert, Johanna M. and Sheila Kirschbaum. "How Museum Teachers Scaffold Emergent Bilingual Learners' Meaning-making During Field Trips," Journal of Museum Education 44, no. 4 (2019): 439-47. https://doi.org/10.1080/10598650. 2019.1673114

Tucker, Faith and John Horton. “'The show must go on!' Fieldwork, mental health and wellbeing in Geography, Earth and Environmental Sciences," Area 51, no. 1 (2019): 84-93. https://doi.org/10.1111/area.12437

Uttal, David H., Nathaniel G. Meadow, Elizabeth T. Tipton, Linda L. Hand, Alison R. Alden, and Christopher Warren (2013), "The Malleability of Spatial Skills: A Meta-Analysis of Training Studies", Psychological Bulletin 139, no. 2 (2013): 352-402. https://doi.org/10.1037/a0028446

VanSledright, Bruce A. The challenge of rethinking history education: On practices, theories, and policy. New York and London: Routledge, 2011. https://doi. org/10.4324/9780203844847

Wiseheart, Melody, Mythili Viswanathan and Ellen Bialystok. "Flexibility in task switching by monolinguals and bilinguals," Bilingualism: Language and Cognition 19, no. 1 (2015): 141-6. https://doi.org/10.1017/S1366728914000273

Wolff, Dieter. "Integrating language and content in the language classroom: Are transfer of knowledge and of language ensured?," ASp 41/42 (2003): 35-46. https://doi.org/10.4000/asp.1154

Zhang, Jijia, Yutong Lu, Qirui Zhang, and Jinquiao Zhang. "The effects of foreign language anxiety, nervousness and cognitive load on foreign language lying: Evidence from Chinese-English bilinguals," Acta Psychologica Sinica 52, no.7 (2020): 861-73. https://doi.org/10.3724/SP.J.1041.2020.00861

\section{About the authors}

CARLOS MARTÍNEZ-HERNÁNDEZ (cmartinezhernandez@ucm.es) is Doctor in Geography and he works as PhD Assistant Lecturer in Didactics of Social Sciences in the Faculty of Education - Teacher Training Centre, Complutense University of Madrid, Rector Royo Villanova Street, 1, 28040 Madrid, Spain. He has experience in research and teaching of Environmental Sciences, Geography and Didactics of Social Sciences (land uses, teacher training, didactic fieldtrips, GIS in education, tourism teaching). He has carried his teaching and research career in the Universities of Murcia, ISEN Cartagena and Complutense of Madrid. He has also worked as a researcher in the Universities of Málaga and Amsterdam. His ORCID is: https://orcid.org/0000-0002-6526-6905. 
SARA ALBALADEJO-ALBALADEJO (sara.albaladejo@um.es) works as Associate Lecturer in the Faculty of Education, University of Murcia, Espinardo Campus, 30100 Murcia, Spain. She has experience of several years of teaching at university level and conducting research as a master's and PhD Student. Her principle fields of research are English as a foreign language, teacher training, and pronunciation teaching and learning. 


\title{
Geohistorical, didactic, and linguistic competencies learning through a bilingual (Spanish/English) fieldtrip project with teachers in training
}

\author{
Carlos Martínez-Hernández and Sara Albaladejo-Albaladejo
}

doi: http://dx.doi.org/10.18543/tjhe-9(1)-2021pp65-102

\section{Copyright}

Copyright for this article is retained by the Publisher. It is an Open Access material that is free for full online access, download, storage, distribution, and or reuse in any medium only for noncommercial purposes and in compliance with any applicable copyright legislation, without prior permission from the Publisher or the author(s). In any case, proper acknowledgement of the original publication source must be made and any changes to the original work must be indicated clearly and in a manner that does not suggest the author's and or Publisher's endorsement whatsoever. Any other use of its content in any medium or format, now known or developed in the future, requires prior written permission of the copyright holder. 